Florida International University FIU Digital Commons

4-6-1992

\title{
Civil-military relations in Guatemala during the Cerezo presidency
}

Laura A. Cole

Florida International University

DOI: $10.25148 /$ etd.FI14060874

Follow this and additional works at: https://digitalcommons.fiu.edu/etd

Part of the Latin American Studies Commons

\section{Recommended Citation}

Cole, Laura A., "Civil-military relations in Guatemala during the Cerezo presidency" (1992). FIU Electronic Theses and Dissertations. 2404.

https://digitalcommons.fiu.edu/etd/2404

This work is brought to you for free and open access by the University Graduate School at FIU Digital Commons. It has been accepted for inclusion in FIU Electronic Theses and Dissertations by an authorized administrator of FIU Digital Commons. For more information, please contact dcc@fiu.edu. 
Civil-Military Relations in Guatemala During the Cerezo Presidency

by

\author{
Laura A. Cole \\ Florida International University, 1992 \\ Miami, Florida \\ Professor Eduardo Gamarra, Major Professor
}

In 1986 Guatemala experienced a transition from authoritarian rule. Many issues affected the democratization process, but I argue that an essential aspect was civilmilitary relations. Thus, the principal question answered in this thesis is: How have civil-military relations determined the extent and nature of transition towards democracy in Guatemala from 1986-1990?

Adopting Alfred Stepan's model to examine civil-military relations, the prerogatives and contestation of the Guatemalan military were examined. Prerogatives exist when the military assumes the right to control an issue, while contestation involves open articulated conflict with civilian government. High military prerogatives and low contestation indicate a situation of unequal civilian accommodation, where civilians do not effectively control the military. 
Civil-military relations in Guatemala from 1986-1990 reflect a pattern of unequal civilian accommodation. This illustrates the lack of civilian control over the military and continued military dominance of the political system in Guatemala. 


\title{
FLORIDA INTERNATIONAL UNIVERSITY \\ Miami, Florida
}

\author{
Civil-Military Relations in Guatemala During the \\ Cerezo Presidency
}

A thesis submitted in partial satisfaction of the requirements for the degree of Master of Arts in International studies

by

Laura A. Cole 
To Professors Gamarra, Moreno and Kincaid:

This thesis, having been approved in respect to form and mechanical execution, is referred to you for judgement upon its substantial merit.

Dean Arthur Herriott

College of Arts and Sciences

The thesis of Laura A. Cole is approved.

Dario Moreno

Douglas Kincaid

Eduardo Gamarra, Major Professor

Date of Examination: April 6, 1992

Dean Richard L. Campbell

Division of Graduate studies

Florida International University, 1992 
LIST OF TABLES . . . . . . . . . . . . . . . . . . V CHAPTER ONE . . . . . . . . . . . . . . . . 1

Introduction

Latin American Militaries and Praetorian Societies

Military Intervention in Politics

Military Withdrawal

Civil-Military Relations in the Post Transition Period

CHAPTER TWO . . . . . . . . . . . . . . . 25

Political Background

Development of Counterinsurgency war

Economic Decline and Human Rights Abuses

The Military Produces International Isolation

Role of U.S. Military Aid

Military Mission and structure

The Military as an Economic Player

Divisions in the Military

CHAPTER THREE . . . . . . . . . . . . . . 56

Establishing Prerogatives

Limitations Before Inauguration

Human Rights

U.S. Role 
Military Budget

Security Issues

coups and Change

CHAPTER FOUR . . . . . . . . . . . . . . . 82

Conclusions

WORKS CITED . . . . . . . . . . . . . . . 97 


\section{LIST OF TABLES}

TABLE

PAGE

1. The Levels of Military Intervention . . . . . 10

2. Contestation, Prerogatives, and Civil-Military Relations . . . . . . . . . . . . . . 21

3. Guatemalan Leaders 1931-1991 . . . . . . . . 27

4. Selected Economic Data for Guatemala . . . . 36

5. U.S. Assistance to Guatemala . . . . . . . . 41

6. Guatemalan Military Expenditures . . . . . . . 72 


\section{CHAPTER ONE}

\section{INTRODUCTION}

During the 1980s, a wave of transitions from authoritarian rule swept through Latin America. In light of the legacy of brutal military regimes, prospects for democratization after the installation of civilian government have been discussed at great length. Many authors argue that the characteristics of civil-military relations will determine the success of transition. This thesis, a case study of Guatemala's recent transition from authoritarian rule, will utilize existing literature as a guide for examination of a specific case. Following Alfred Stepan, I will argue that an essential aspect of democratization concerns civil-military relations. In short, I maintain that to deepen the process of democratization, civilian rulers must establish effective control over the military. 'Thus, the principal question to seek to answer is: How have civil-military relations determined the extent and nature of transition towards democracy in Guatemala from 1986-1990?

'Alfred Stepan, Rethinking Military Politics: Brazil and the Southern Cone (Princeton: Princeton University Press, 1988), 128. 
This thesis will attempt to accomplish several things. First, a review of relevant literature will assess the usefulness of different approaches in examining civil-military relations. Also, an examination will be made of the effect of United states military assistance on the transition process. Finally, an effort will be made to illuminate the prospects for civilian governance in Guatemala as affected by the dynamics of civil-military relations in the period following direct military rule.

For purposes of this thesis, a transition will be defined as political change from an authoritarian regime to a liberaldemocratic one. Transitions could also occur through revolutionary change; however, the transitions to be examined here will consider only movements toward civilian democracies through elections.

In the democratic transition model, one "departs" from autocratic regimes (illegitimate administrations, controlled by the military, that resort to repressive mechanisms to manage civilian society) and "arrives" at legitimate, civilian-controlled governments, whose relations with civilian societies are based on consent. 2

Liberalization, an opening of the system and loosening of control, can occur without democratization. For purposes of

2Gabriel Aguilera, "The Armed Forces, Democracy, and Transition in Central America," in The Military and Democracy: The Future of Civil-Military Relations in Latin America, eds. Louis W. Goodman, Johanna S.R. Mendelson, and Juan Rial (Lexington: Lexington Books, 1990), 23. 
this thesis, democratization will refer to the movement of a society towards a representative form of government responsive to the preferences of its citizens regardless of the source or content. ${ }^{3}$ More precisely, democratization implies open contestation for control of the government with free elections which decide who governs. ${ }^{4}$

Military governments in Latin America have been commonplace, but their duration and stability have often proved temporary. 5 These periods of military rule profoundly influence the process of governance which follows a retreat to the barracks. The literature on the military devotes much attention to coups and the performance of officers as governors. Few works are available, however, which assess civil-military relations during the period after a transfer from military to civilian government. In examining civilmilitary relations after or during a transition, it may be useful to know what brings the military to government and why it chooses to intervene. Also, it will be useful to consider the nature of this military and the society in which it operates. After a review of the main factors leading to

${ }^{3}$ Robert Dahl, Polyarchy (New Haven: Yale University Press, 1971), 1-2.

${ }^{4}$ Stepan, 6 .

${ }^{5}$ Eric A. Nordlinger, Soldiers in Politics (Englewood Cliffs, NJ: Prentice Hal1, 1977), 138; and Alain Rouquié, The Military and the State in Latin America (Berkeley: University of California Press, 1987), 345. 
military withdrawal from politics the chapter discusses civilmilitary relations during the change to civilian government and after.

\section{LATIN AMERICAN MILITARIES AND PRAETORIAN SOCIETIES}

Huntington proposes that the armed forces of Latin America may not be fully professional institutions, but relative to other groups in society, they are often the most coherent. Possessing an organizational coherence, the military is often the only group in society which, in times of economic or political crisis, is able to control the government apparatus. ${ }^{6}$ Much of the literature focuses on why the military intervenes in politics. Authors, such as samuel Huntington, argue that military rationale for intervening in politics rests in a sense of mission to protect the nation. This may mean removing a civilian government through a coup, and replacing it with a military government to save the nation from what it views as the perils of civilian rule. At times the military sense of mission may override loyalty to existing authority. ${ }^{7}$

The weakness of civilian institutions leads to greater military involvement in social, economic and political

${ }^{6}$ Samuel Huntington, political order in changing societies (New Haven: Yale University Press, 1968), 217.

${ }^{7}$ Nordlinger, $19-20$. 
spheres. This has been termed "reactive militarism," meaning that the military expands its role as a result of civilian weakness. 8

The extent to which military institutions and individuals become politicized is a function of the weakness of civilian political organizations and the inability of civilian political leaders to deal with the principal policy problems facing the country.9

Many authors have noted that the military's coherence in intervening in politics is often, if not always, aided by encouragement from sectors of civil society. ${ }^{10}$

The above discussion does not imply a lack of internal conflict within the military institution. Rather, it presents the military as possessing a measure of organization, cohesion and institutionalization enabling it to act decisively at certain key moments in Latin American polities. This coherence allows the military to take a direct role in governance. 11 Existing differences based on ethnicity, class, generation and branch of service are often exacerbated by military rule. other conflicts, over power, the spoils of

Morris Janowitz, The Military in the political Development of New Nations (Chicago: University of Chicago Press, 1964), 4-5, 85.

${ }^{9}$ Huntington, 221.

${ }^{10}$ Stepan, 128 .

"Huntington, 217 . 
office and ideology, are more directly caused by governance. ${ }^{12}$ To understand these issues, I will first examine the causes of military intervention and the type of society which is prone to intervention.

Latin American societies have often been defined as praetorian. A praetorian society is one in which all social forces, clergies, universities, labor unions, militaries, etc., are politicized. Social groups become concerned with general political issues, rather than with only specific issues relevant to the particular group. In a praetorian society, the rules of the political game are not agreed upon by the different players in the political system. Each group resorts to whatever methods are at its disposal to influence the political system, and no recognized methods for conflict resolution exist. In such a society, the military uses its superior force to intervene in politics. By the threat of force, the use of force, or direct control of the government, the military becomes the most influential political actor. ${ }^{13}$ The following describes conflict in this type of system:

${ }^{12} \mathrm{Jan}$ Knippers Black, Sentinels of the Empire: The United States and Latin American Militarism (New York: Greenwood Press, 1986), 90-91.

${ }^{13}$ Huntington, 194-197; and Nordlinger, 2-3. 
In a praetorian system social forces confront each other nakedly; no political institutions, no corps of professional political leaders are recognized or accepted as the legitimate intermediaries to moderate group conflict. Equally important, no agreement exists among the groups as to the legitimate and authoritative methods for resolving conflicts. ${ }^{14}$

Praetorianism is a useful concept in understanding the military's resort to violence as a means for achieving political goals.

\section{MILITARY INTERVENTION IN POLITICS}

The military in Latin America may intervene for several reasons. Extensive U.S. training in the post World War II era led to a National security Doctrine. The enemy of these militaries, as defined by the U.S., was internal rather than external. ${ }^{15}$ Latin American militaries sought to prevent the rise of other social groups or popular movements from gaining power. ${ }^{16}$ In the context of the cold War, the U.S. sought to strengthen the Right, and the military gained a strong corporate consciousness. Having developed a repressive capability and a sense of competence, the military often felt

${ }^{14}$ Huntington, 196.

${ }^{15} \mathrm{Black}, 40-43$.

${ }^{16}$ Guillermo O'Donnell and Philippe Schmitter, Tentative Conclusions about Uncertain Democracies (Baltimore and London: Johns Hopkins University Press, 1986), 15-17: and Huntington 231-233. 
that it was more capable than civilians to run the country. During this process, the U.S. often encouraged the political aspirations of the military as well, through training, aid and promoting increased self confidence of the armed forces. ${ }^{17}$

Military intervention is related to the sense of mission discussed above, but also to the levels of political participation in a society. The military can play a different role during various stages of political development. According to Huntington,

As society changes, so does the role of the military. In the world of oligarchy, the soldier is a radical; in the middleclass world he is a participant and arbiter; as the mass society looms on the horizon he becomes the conservative guardian of the existing order. ${ }^{18}$

In a radical praetorian system, the city (urban areas) becomes the center of political influence in place of rural areas, reflecting the gap between the city and the country. The instability caused by this shift (from rural to urban) leads the military to intervene to bring the middle sectors into the political game. This entrance of middle class groups into politics marks the beginning of radical praetorianism. In a radical praetorian society, social groups use the means at their disposal to try to influence existing authority rather than to exercise authority. Once the middle classes become

$$
\begin{aligned}
& { }^{17} \text { Black, } 40-42 . \\
& { }^{18} \text { Ibid., } 221 .
\end{aligned}
$$


the established force in politics, the military plays a stabilizing role. Whether or not effective institutions are formed to deal with mass participation determines the role of the military in a mass society. ${ }^{19}$

If institutions are created to deal with mass participation, the military may become apolitical and professional. But, if this is not the case, the military will protect the middle class order from the lower classes. Thus the military becomes a guardian, and prevents the broadening of political participation. ${ }^{20}$

If the army judges that the republic is
in danger, that disorder is in prospect,
it has the obligation to intervene and to
restore the constitution. once this is
done, it then has the obligation to
withdraw and to return power to the
normal (conservative, middle-class)
civilian leaders.21

In this sense, the military exercises a veto over the system. 22

Huntington's stages of praetorianism provide a historical perspective as to the development of praetorian systems. Eric A. Nordlinger explains different types of military intervention in politics in relation to the goals of the

${ }^{19}$ Ibid. , 209-212, 222.

${ }^{20}$ Ibid. , $222,224$.

${ }^{21}$ Ibid. , 227.

${ }^{22}$ Ibid. , 228. 
military, which may provide greater insight into patterns of civil-military relations. TABLE 1 summarizes the roles and objectives of the military.

\section{Table 1 \\ The Levels of Military Intervention}

\begin{tabular}{|c|c|c|c|}
\hline & Moderators & Guardians & Rulers \\
\hline Extent of Power & Volo power & $\begin{array}{l}\text { Govemmental } \\
\text { control }\end{array}$ & $\begin{array}{l}\text { Regime } \\
\text { dominance }\end{array}$ \\
\hline $\begin{array}{l}\text { Polltical and economic } \\
\text { objectives }\end{array}$ & $\begin{array}{l}\text { Preserve } \\
\text { status quo }\end{array}$ & $\begin{array}{l}\text { Preserve } \\
\text { status quo } \\
\text { and/or correct } \\
\text { malpractices and } \\
\text { deflclencles }\end{array}$ & $\begin{array}{l}\text { Effect polltical } \\
\text { change and } \\
\text { sometimas } \\
\text { socioeconomic } \\
\text { change }\end{array}$ \\
\hline
\end{tabular}

Source: Eric A. Nordlinger, Soldiers in Politics (Englewood Cliffs, NY: Prentice Hall, 1977), 22.

Each role brings different levels of military participation. If the military plays the role of moderator, civilians govern, but do not exercise effective control. Direct control of the government is not needed to achieve the goals of the military as moderator. Often, moderators will become guardians or rulers. Guardians pursue much the same objectives as moderators, but see direct control of the government for a short period as the only means. Rulers have more ambitious goals, and set out to control the government and dominate the regime. Military rulers may only mention a return to civilian 
government at an unspecified date. ${ }^{23}$

While the likelihood of moving from a moderator to a guardian or ruler role is discussed, moving the opposite direction is not. Options for a return to civilian government are presented, but it would seem possible to move from a more extreme form of intervention to a milder one. This would mean the continuation of a praetorian system, but the possibility of improvement within it. The way it was presented by Nordlinger suggests that this is unlikely. In my view, reducing the role of the military in politics seems a much more likely option than eliminating its role altogether. This approach deals mainly with military rationale for intervention in politics, not necessarily in a post transition setting or post transfer of the reins of government. As such, it does not provide a meaningful way to examine relevant elements of civil-military relations after a change to civilian government.

\section{MILITARY WITHDRAWAL}

Military rulers often find governance a more difficult task than they anticipate, and unlike civilians who can choose politics as a full time vocation, the military serves other functions, such as defending its corporate interest and preserving the security of the nation. Once in control of the

${ }^{23}$ Nordlinger, $21-26$. 
government, militaries often find that governance does not go as smoothly as planned. As rulers, militaries usually prove no more competent than civilians, and so believing that their policies are unlikely to be reversed after a transition, withdrawal is used to preserve the public image of the military. Often the armed forces will take over government without explicit goals, which can cause conflict within the institution itself, over policies or the duration of military rule and proper time for disengagement. ${ }^{24}$

Military institutions may withdraw from direct governance for many reasons -- to preserve military unity threatened by rivalries created by the duties of ruling, the general political-economic climate involving human rights, foreign aid conditionality, loan reviews, concerns of transnational corporations, the debt crisis, some factions profiting more from the spoils of office, ideology, regional conflict, and conflict among branches of service. ${ }^{25}$ Mismanaging the economy and increasing corruption, the military often proves no more competent in dealing with economic crisis than civilians. Many of these issues are seen by some in the military to impair efforts to defeat guerrilla movements

${ }^{24}$ Nordlinger, $142-146$.

${ }^{25}$ George A. Lopez and Michael Stohl, "Liberalization and Redemocratization in Latin America: The Search for Models and Meanings," in Liberalization and Redemocratization in Latin America, eds. George A. Lopez and Michael Stohl (New York: Greenwood Press, 1987), 8; and Black, 90-91. 
within their societies. Some factions are concerned only with the guerrillas, and others with how the crisis in the economy and extensive repression makes the war situation worse. Often these military governments face a decline in international support as well. 26

When considering a change from military to civilian government, the key issue of dissension in the armed forces between the "hard-liners" and the "soft-liners" rests in the issue of return to civilian government. Hard-liners are more radical and essentially authoritarian in their politics. They would like to structurally reform the political system and permanently prevent the civilian groups they replaced from returning to power. Soft-liners are moderate, with more limited goals in taking control of the government. They may only want to remove a few political leaders and make minor administrative changes. The hard-liners maintain that they can and should perpetuate their rule, often believing that popular movements and democracy are disorders in society which they must remove or prevent. The soft-liners may agree generally with this point of view, but also see the eventual need for legitimation through some type of electoral process. 27

It is important to note that when the military is not

${ }^{26}$ Aguilera, 27.

270'Donnell and Schmitter, 15-17; and Huntington, 231-232. 
forcibly removed from power, it will play a crucial role in shaping the new government. The military may see a transition as an effective and efficient option for their own goals at the time. ${ }^{28}$ Nordlinger observed that there are several paths to civilian rule, only one of which appears possible. The first would be that the military is forced from office by extensive civilian opposition, but civilian groups are unlikely to be strong enough to do this. The second would be that officers outside the government overthrow the military rulers, and then turn the government over to civilians. It seems unlikely, though, that such a countercoup would relinquish power to civilians. Lastly, the military may voluntarily disengage from government. According to Nordlinger, this is the most feasible path, although this does not necessarily lead to civilian rule. Instead, the military may play the role of moderator and control the state without directly holding office. ${ }^{29}$ Basically this assessment of paths to disengagement seems appropriate, but not helpful in determining configurations of civil-military relations after military withdrawal and subsequent effects on governance.

In a mass praetorian system, where the military is the guardian of existing middle class order, veto coups are used

${ }^{28}$ Douglas A. Chalmers and Craig H. Robinson, "Why Power contenders Choose Liberalization," International studies Quarterly 26 no. 1 (March 1982), 5-7.

${ }^{29}$ Nordlinger, $139-141$. 
by the armed forces to ensure that the government does not pursue policies that the military disapproves of. If the military intervenes in this way, it has several options. The armed forces can retain control of the government and restrict participation, which may lead to more repression, or retain control and allow an expansion of participation. The other two options would be if the military returned government to civilians, and either restricted participation of new groups, or expanded participation of new groups. A return to civilian government with an expansion of participation would be ideal in the sense of a transition; however, this is complicated by the lack of community and institutions in civil society. This traps the society in a state of praetorianism, which leads to repeated military intervention. At this juncture, Nordlinger sees the military as institution builder as possibly the only chance for escaping the cycle of praetorianism. ${ }^{30}$

The military may leave office without leaving power. The best protection against democracy may be the procedures of democracy. By allowing elections and some participation, the military may diffuse demands for greater change and liberalization. Attempts by the armed forces to legalize the system lead to continued military power. An honorable way out for the military is to hold elections to get democratic endorsement of a government. The problem with such an

${ }^{30}$ Ibid. , $233-240$. 
election lies in the methods used by the military to ensure that certain candidates will be or not be elected. Through a "controlled and coercive multiparty system" or a "dominant military party" the armed forces will continue to control the government. ". . legalization often does not have full and complete democracy as its goal."131

If the military agrees to withdraw from government, certain conditions may be set. When retreating from direct rule, the military will often try to limit civilian authority over its internal operations, as well as provide immunity for past crimes and establish certain "power provinces" for continued military dominance. ${ }^{32}$ The armed forces may require a veto power over candidates for office, or force civilians to nominate preferred military officers or candidates to high appointed offices, especially those responsible for the military. Although Rouquié does not seem to adequately describe how civilians might gain control over the military, he allows for the possibility that military intervention in politics can become a thing of the past. "The longer military intervention does not take place, the more civilian power is reinforced, military usurpation made more difficult, and the political system demilitarized."33 Civilians may have to

\footnotetext{
${ }^{31}$ Rouquié, $351-354,368$.

${ }^{32}$ Aguilera, 32.

${ }^{33}$ Rouquié, 364 .
} 
give concessions to move forward, and the military might only withdraw as a tactical move or to regroup. ${ }^{34}$

Many aspects of the international system make this wave of democratization unique. With the collapse of Eastern Europe and the Soviet Union, democratic government holds much prestige in an international context. Also, this signals the end of the cold War, which means that the rationale of the National security state needs to be reevaluated. Since subversive leftists are no longer the main concern of the U.S., policies have changed. The U.S. has placed increasing importance on democratic government in relations with Latin America, especially in the disbursement of military aid.

Rouquie notes that the main impetus for democratization or military withdrawal from politics comes from within the military itself, ${ }^{35}$ while others might assert that pressure from the United states plays a decisive role. ${ }^{36}$ The U.S. has attempted to promote democratic government through foreign assistance policies. The amount of influence gained through economic and military aid is by no means clear. Examination of specific cases may provide insight. If the policy objective of the U.S. is a transition from authoritarian rule,

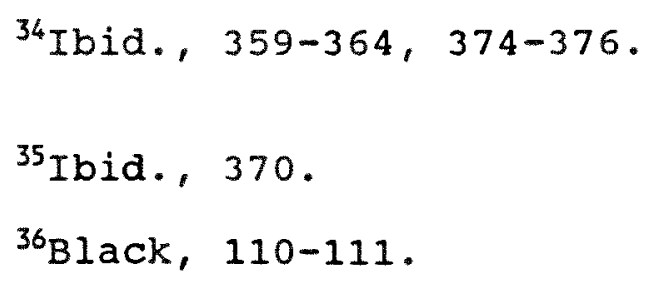


does withholding military aid lead to the desired result? What is the capacity of Latin American militaries to act autonomously in spite of U.S. sanctions?

\section{CIVIL-MILITARY RELATIONS IN THE POST TRANSITION PERIOD}

The focus of much of the literature on civil-military relations centers on coups or processes leading to intervention in politics, the period of direct military rule, the decision to disengage from government, or even potential configurations of civil-military relations. Less attention is focused on the period following a transition from military to civilian government and the factors which lead to a strengthening of civilian control or failure and continued military dominance. Alfred stepan has devised a useful model to analyze the relationship between civilians and the military after a transfer from military to civilian government with attention to areas of potential conflict. ${ }^{37}$

The two main areas selected to examine the amount of civilian control are the dimension of articulated military contestation (against policies of the new government) and the dimension of military institutional prerogatives. There are several areas for potential conflict between the military and a new civilian government. These are the human rights abuses of the previous regime and how they will be handled,

$$
{ }^{37} \text { stepan, } 68 \text {. }
$$


democratic government attempts to change the organizational mission and structure of the military (control the military), and the military budget. ${ }^{38}$

Military prerogatives are a bit complex.

For our purposes, the dimension of military institutional prerogatives refers to those areas where, whether challenged or not, the military as an institution assumes they have an acquired right or privilege, formal or informal, to exercise effective control over its internal governance, to play a role within extramilitary areas within the state apparatus, or even to structure relationships between the state and political or civil society. ${ }^{39}$

Low levels of prerogatives exist when a civilian government holds de jure and de facto control over an issue area. If the military is denied de jure control, but engages in noncompliance, then the military prerogative would be considered moderate. An area where this may be visible is when the military is constitutionally subject to civilian control and authority, but de facto the military remains autonomous. Other prerogative areas are: Military relationship to the chief executive (Who has de jure and de facto control?), and the role of the military in cabinet positions, intelligence, military promotions, and the legal system (Are military officers generally subject to civil laws

$$
\begin{aligned}
& { }^{38} \text { Ibid. } \\
& { }^{39} \text { Ibid. , } 93 .
\end{aligned}
$$


and courts or military justice?). ${ }^{40}$

These prerogatives are closely related to military contestation. Potentially every prerogative area could be contested by the military. Contestation involves open articulated conflict with civilian authorities. This would indicate that the relevant civilian and military actors are aware of the conflict over policies. Lack of contestation does not necessarily imply a lack of prerogative in a particular area. By comparing the levels of both, several relationships are possible. When both are low, civilian control results. If the two dimensions are plotted against each other, this would be the area in the lower left corner (see TABLE 2). Intense conflict between the military and civilians where contestation and prerogatives are high would be a nearly impossible position for civilians to sustain (upper right on chart). The upper left position while analytically possible is unlikely in reality. It would not make sense in a situation of de jure and de facto civilian control for the military to engage in high levels of contestation. ${ }^{41}$

\footnotetext{
${ }^{40}$ Ibid. , 93-97.

${ }^{41}$ Ibid. , 68, 98-102.
} 
TABLE 2

CONTESTATION, PREROGATIVES. AND CIVIL MILITARY RELATIONS

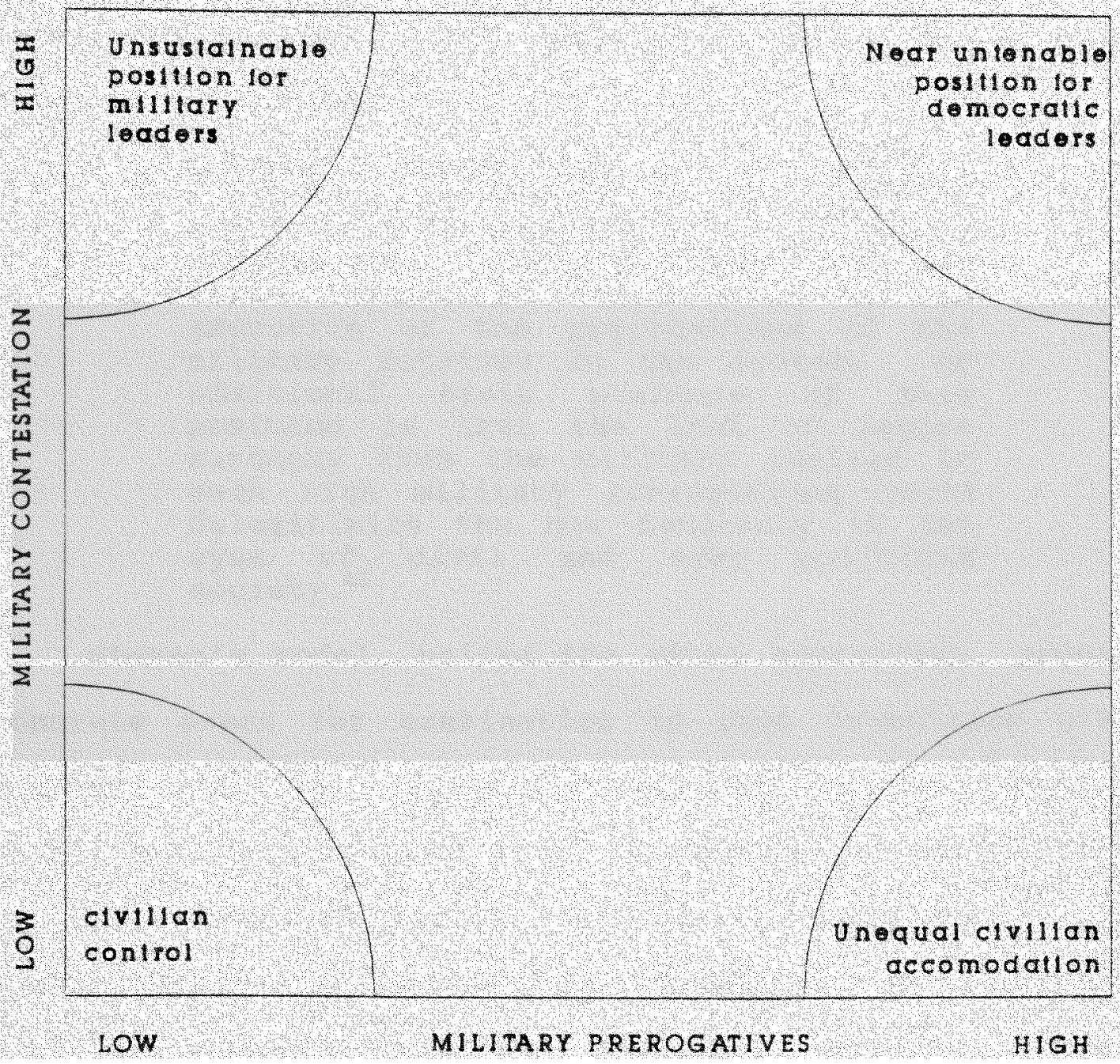

Source: Alfred stepan, Rethinking Military Politics: Brazil and the Southern cone (Princeton: Princeton University Press, $1988), 100$.

The relationship of unequal civilian accommodation (lower right) is perhaps the most interesting, considering the possibility for change. This model is dynamic and subject to shifts of any magnitude; therefore, a position of unequal civilian accommodation could be consolidated into a 
democratic system. This relationship may be extremely useful in analyzing Guatemala and prospects for democracy since the transition in 1986. Some aspects of this position appear relevant to Guatemala:

Another vulnerability of the 'unequal civilian accommodation' position is that a polity could become transformed into a nondemocratic civilian-headed garrison state because of exploitation by the executive of the prerogatives of the military retained in the system. An additional basic weakness of this position is that the lack of regime autonomy from the military implied in such high military prerogatives could delegitimize the new democracy in the eyes of civil and even political society. ${ }^{2}$

Stepan's model, unlike the other approaches, provides concrete areas for examination in post transition civilmilitary relations. In my opinion, civil-military relations is the most crucial issue in discussing democratic governance in Latin American states that have experienced military authoritarian rule in the past. Previously, this model was applied to South America. Guatemala provides a unique opportunity to broaden the range of countries analyzed to Central America. Military rule ran practically uninterrupted in Guatemala for thirty years prior to the transfer of government in 1986. Thus, civil-military relations are crucial to understanding prospects for democratic governance

$$
{ }^{42} \text { Ibid. , } 101 .
$$


in the future.

Guatemala today, although nominally headed by civilian government, remains likely the most repressive military regime in the Western hemisphere. This Central American nation, controlled by the military, was allowed to undergo relatively free elections in 1985, and witnessed the installation of a civilian president in 1986. The last interlude of civilian rule experienced by Guatemala occurred during the revolutionary period from 1944-1954. So why would the entrenched, institutionalized military of the early 1980s allow this apparent transition and what are the prospects for a democratic consolidation of civilian rule? The period from 1986-1990 represents the first completed term in office for a civilian president after the military turned over the official reins of government. Even though the term was completed and a peaceful transfer of power occurred in 1991, the extent of transition was not clear. In my view, the most significant, but not the only, dimension to gauge progress towards democratic governance is the nature of civil-military relations. Thus, the principal question to seek to answer is: How have civil-military relations determined the extent and nature of transition towards democracy in Guatemala from 1986$1990 ?$

Using Guatemala as a case study of a recent change from military to civilian government it will be possible to apply 
Stepan's model of civil-military relations in a transition from authoritarian rule. The analysis will be based on information collected from primary and secondary sources as well as personal interviews by the author. The remainder of this thesis has several objectives. First, a review of the historical context in Guatemala will aid in a discussion of prerogatives and contestation in the period after military withdrawal. Secondly, the degree of U.S. influence through military aid in affecting the installation of civilian government will be examined. Lastly, a summary of the research, conclusions, and an assessment of the nature of civil-military relations in Guatemala will lead to a final expectation of this thesis which is to test the validity of Stepan's model. Considering that the model was developed to examine Brazil and the Southern cone, this case study should provide a very useful gauge of the method in a comparative setting. 


\section{CHAPTER TWO}

\section{POLITICAL BACKGROUND}

Guatemala is the largest country in Central America, located just south of Mexico, and is bordered by Belize, Honduras and El Salvador. Much of the population is of Mayan descent, although only about one-third is identified as Indian now. The other two thirds can be termed Ladino, which may indicate spanish-Mayan descent, but more importantly identifies those who have adopted Western dress and lifestyle. The Maya of the rural highlands are still for the most part excluded from politics. The majority of the population is poor and marginalized. Racial and class tensions are strong, with Indian used as a derogatory term. ${ }^{1}$ control of these Indian masses in the countryside is important in understanding Guatemalan politics.

Politics in Guatemala from the time of independence from Spain have been controlled by small groups often through violent means. Even when the formal trappings of democracy have been in place, it has been in name only. A brief history

'For a more complete discussion see Peter Calvert, Guatemala: A Nation in Turmoil (Boulder: Westview Press, 1985). 
will be useful to set the stage for the transition and afterwards. The political arena in Guatemala until 1944 was dominated by personalistic leaders. From 1898-1920, the country was controlled by Manuel Estrada Cabrera, who relied on a few individuals rather than a military institution to perpetuate his rule. Later, General Jorge Ubico ruled with U.S. State Department backing from 1931-1944. Neither of these caudilios, although they employed repression, depended on the military as an institution to sustain their regimes. In spite of this, Ubico militarized the society in a significant way. He extended military operations in the countryside, making the armed forces dominant in this area. This transformation remains essential in explaining military prerogatives until the present time. ${ }^{2}$

The two successive administrations of Juan José Arévalo and Jacobo Arbenz Guzmán (1944-1954) represent the last period of legitimate, elected presidential government in Guatemala until 1986. The "Revolution" from 1944-1954 began when Ubico was ousted due to popular unrest. When his successor, the head of a junta, indicated that he wanted to pursue a similar style personal dictatorship, younger officers moved against the ruling junta. The elected government of Arévalo (19441950) faced more than thirty coup attempts, but was not

${ }^{2} \mathrm{Jim}$ Handy, "Resurgent Democracy and the Guatemalan Military," Journal of Latin American Studies 18 no. 2 (November 1986): 386-387. 
toppled because the bulk of the military did not support the coups. Captain Jacobo Arbenz, one of the leaders of the revolt in 1944, became President of Guatemala in 1950. Arbenz enjoyed some military support, and although the armed forces did not always approve, he pursued reforms, most importantly agrarian reform. ${ }^{3}$

TABLE 3

GUATEMALAN LEADERS 1931-1991

\begin{tabular}{|c|l|}
\hline $1931-1944$ & General Jorge Ubico \\
\hline $1944-1950$ & Juan José Arévalo \\
\hline $1950-1954$ & Captain Jacobo Arbenz Guzmán \\
\hline $1954-1957$ & Castillo Armas-Liberation leader \\
\hline $1958-1963$ & General Miguel Ydigoras Fuentes \\
\hline $1963-1966$ & Colonel Enrique Peralta Azurdia \\
\hline $1966-1970$ & Julio César Méndez Montenegro \\
\hline $1970-1974$ & Colonel Carlos Arana Osorio \\
\hline $1974-1978$ & General Kjell Laugerud \\
\hline $1978-1982$ & General Romeo Lucas Garcia \\
\hline $1982-1983$ & General Efraín Rios Montt \\
\hline $1983-1986$ & General Mejia Victores \\
\hline $1986-1991$ & Vinicio Cerezo \\
\hline $1991-?$ & Jorge Serrano \\
\hline
\end{tabular}

DEVELOPMENT OF COUNTERINSURGENCY WAR

In 1954, the United States' Central Intelligence Agency

${ }^{3}$ Ibid., $388-390$. 
aided and promoted an overthrow of Arbenz's government on the grounds that it was communist. Though not a communist, his mistake was to institute land reform supported by the communists. 4 It is argued that one of the main factors influencing the U.S. decision was an attempt to apply the agrarian reform to lands owned by the United Fruit Company. Consequently, the U.S. organized a Liberation army of exiles and mexcenaries in Honduras, as well as fostering internal opposition. 5

A significant aspect of the overthrow of the Arbenz government is the military's refusal to defend the country against the invasion of the Liberation forces. Arbenz had encouraged peasant organization in rural areas, and as a result, the military was losing influence in the countryside. 6 This prerogative, to dominate the countryside, as mentioned above, plays a crucial role in the part the military takes in politics.

The 1954 coup led to the formation of guerrilla groups,

"Jim Handy, " The Most Precious Fruit of the Revolution': The Guatemalan Agrarian Reform, 1952-54," Hispanic American Historical Review 68 no. 4 (November 1988): 700 ; Allan Nairn and Jean-Marie Simon, "Bureaucracy of Death," The New Republic (30 June 1986): 15.

${ }^{5}$ Handy, "Resurgent Democracy," 390.

'Ibid., 391. 
both Communist and not. ${ }^{7}$ The Guatemalan military then used lists from different groups which supported Arbenz to classify 70,000 people as Communists, employing these records to begin the counterinsurgency war that continues today, and establishing a prerogative in the area of counterinsurgency. Instead of focusing on eradicating communist guerrillas, the military expanded operations to target anyone suspected of being a guerrilla, of being a potential guerrilla, or of supporting guerrillas. ${ }^{8}$ Basically, the counterinsurgency of the Guatemalan military proceeded in several stages

transitional purgative anti-Communist
constitutional era, $1966-82$, which relied
on institutionalized state terrorism; and
an even more brutal era of direct
extra-constitutional military rule, March
1982-January 1986.9

The violence in Guatemala ranged from periods of indiscriminate use of widespread murder of entire communities

${ }^{7}$ Alfonso Yurrita, "The Transition from Military to Civilian Rule in Guatemala," in The Military and Democracy: The Future of civil-Military Relations in Latin America, eds. Louis W. Goodman, Johanna S. R. Mendelson and Juan Rial (Lexington, MA: Lexington Books, 1990), 77; John A. Booth and Thomas $W$. Walker, Understanding Central America (Boulder: Westview Press, 1989), 39; and Penny Lernoux, "Guatemala's New Military Order," The Nation, 28 November 1988, 557.

${ }^{8}$ Gordon L. Bowen, "prospects for Liberalization by way of Democratization in Guatemala," in Liberalization and Redemocratization in Latin America, eds. George A. Lopez and Michael Stohl (New York: Greenwood Press, 1987), 37-38, 40; and Nairn and Simon, 15.

'Bowen, "Prospects for Liberalization," 40 . 
to more discriminate killings. ${ }^{10}$

The guerrilla groups which formed after the coup in 1954 wanted to reclaim the unfinished revolution of the previous decade. As the guerrillas evolved and eventually unified into the Unidad Revolucionaria Nacional Guatemalteca (URNG), their ideology was essentially Marxist, acknowledging the need for revolutionary conflict." ${ }^{1}$ The desired establishment of a revolutionary, popular, democratic government had several objectives:

(1) guarantee the elimination of repression; (2) guarantee the provision of the basic needs of the majority of the people by eliminating the political domination of the repressive rich, both national and foreign, who rule Guatemala; (3) guarantee equality between Indians and ladinos; (4) guarantee the creation of a "New Society" in which all patriotic, popular, and democratic sectors will be represented; and (5) guarantee a policy of nonalignment and international cooperation. ${ }^{12}$

Throughout the stages of counterinsurgency, the Guatemalan military has developed an institutional capacity to conduct counterinsurgency and established a National security

${ }^{10}$ piero Gleijeses, "Guatemala," in Latin American and Caribbean Contemporary Record vol. 7, eds. James M. Malloy and Eduardo Gamarra (New York: Holmes and Meier, 1990), B265.

"Caesar D. Sereseres, "The Highlands War in Guatemala," in Latin American Insurgencies, ed. Georges Fauriol (Washington, D.C.: Georgetown University Center for Strategic and International studies, 1985), 109-111.

${ }^{12}$ Ibid. , 111. 
State. Destroying the guerrillas in an effort to defend and protect the nation became the essence of the military's mission. ${ }^{13}$ After the coup in 1954, the Guatemalan military was not well equipped to deal with a guerrilla threat. Having just aided in the overthrow of a "communist" government, the U.S. proceeded to assist the Guatemalan military in enhancing its counterinsurgency skills. ${ }^{14}$ In the early 1960s, the military pursued a type of civic action program in addition to the use of violence. The U.S. supplied aid and advisors to implement this program of "winning the hearts and minds" of the population. Much of this assistance came under the Alliance for Progress as the U.S. helped shape the Guatemalan military's counterinsurgency tactics. ${ }^{15}$

With the election of Julio Méndez Montenegro in 1966, a civilian president forced to allow the military a free reign in counterinsurgency, the tactics turned more towards violence and repression. From this period until 1982, with differing, but always high, levels of terror and murder, the military

${ }^{13}$ Ibid. , 105.

${ }^{14}$ Howard Sharckman, "The Vietnamization of Guatemala: U.S. Counterinsurgency Programs," in Guatemala, eds. Susanne Jonas and David Tobis (Berkeley: North American Congress on Latin America, 1974), 193-194.

${ }^{15}$ Sharckman, $194 ;$ and Yurrita, 79. 
attempted to destroy the guerrillas once and for all. ${ }^{16}$

As the Guatemalan counterinsurgency evolved and escalated, its focus shifted from "winning hearts and minds" to controlling the behavior of the population through outright terror; thus, an essentially localized offensive evolved into a system of totalitarian control. ${ }^{17}$

Some debate exists as to the extent of U.S. involvement in the Guatemalan counterinsurgency campaigns. That the relationship was close seems certain; for example, the U.S. trained Cuban exiles for the Bay of Pigs invasion in bases in Guatemala. ${ }^{18}$ Although the association was close, officially, United States' military personnel served in advisory roles only. ${ }^{19}$ According to retired U.S. General Frederick F. Woerner, who served in Guatemala from 1966-1969, U.S. forces were never used directly in combat. ${ }^{20}$ Even though U.S. forces may not have been directly involved, the U.S. was able to influence the development of counterinsurgency in Guatemala

${ }^{16}$ Eugene K. Keefe, "National Security," in Guatemala: A Country Study, ed. Richard F. Nyrop (Washington: U.S. Government Printing office, 1983), 186; Sharckman, 195, 202203 .

${ }^{17}$ Sharckman, 193.

${ }^{18}$ Keefe, 186.

${ }^{19}$ Sharckman, 198-199.

${ }^{20}$ General Frederick $F$. Woerner, phone interview by author, 20 September 1991. 
through aid, training, advisement and military hardware. ${ }^{21}$

Ríos Montt, a presidential candidate and General in 1974, assumed control of the government in 1982. His association with the military had been weak since 1974, while he pursued activities in a fundamentalist Protestant church. His ties with the Christian Democratic party did not prevent the fervor of counterinsurgency pursued during his government. This phase of counterinsurgency involved procedures to permanently alter the organization of the countryside. By forcing peasants into model villages, civil defense patrols and through the use of civic action programs involving food distribution and re-education, the military aimed at complete control.22 A degree of success was achieved, putting the military in a stable position, which facilitated the transfer from military to civilian government in 1986.

Rios Montt was overthrown in 1983 and replaced by officers led by General Mejía Victores. General Mejía began to reinforce army discipline and prepared for elections in 1985. ${ }^{23}$ Vinicio Cerezo Arévalo, a Christian Democrat, won the elections in a run-off with 68.4 percent of the votes.

${ }^{21}$ Sharckman, 196.

${ }^{22}$ Handy, "Resurgent Democracy," 402-403; Tom Barry, Guatemala: A Country Guide (Albuquerque: The InterHemispheric Education Resource Center, 1989), 41-42; and Sereseres, "Highlands War," 113-115.

${ }^{23} \mathrm{Handy}$, "Resurgent Democracy," 405. 
His party's strong showing reflected the divided nature of the opposition, and was tempered by promises to avoid major land reform and prosecution of officers for human rights abuses in order to placate the military. ${ }^{24}$ At the time of the elections, "The army was in a more powerful position in relation to the other political actors in Guatemala than it had ever been."125

Along with violence from the military institution, the armed forces and private right-wing groups worked through death squads. Much of this activity was supported directly by the military, but private groups such as the secret AntiCommunist Army (ESA), the White Hand and Jaguar of Justice (JJ) have also taken credit for murders. Death squad activity lessened at the beginning of cerezo's term, but rose throughout the rest of his administration (as with human rights violations overall, to be discussed below).$^{26}$

By 1985, the Guatemalan military considered itself to be in control of the country, having massacred tens of thousands of peasants and having destroyed much of the guerrillas' organization. The military held supremacy at this point as a result of scorched earth policies, relocation of peasants in

${ }^{24}$ Richard Millett, "Guatemala," in Latin American and Caribbean Contemporary Record, ed. Abraham F. Lowenthal (New York: Holmes and Meier, 1989), B299.

$$
\begin{aligned}
& { }^{25} \text { Handy, "Resurgent Democracy," 403-405, } 408 . \\
& { }^{26} \text { Barry, 51-52. }
\end{aligned}
$$


model villages (concentration camps), and the creation of Civil Defense Patrols. ${ }^{27}$ But, by 1988, the guerrilla movement seemed to have revived somewhat, despite denials from the army. Military deaths were up from the previous year, and the counterinsurgency war escalated. The army will only accept complete surrender on the part of the guerrillas, and the guerrillas will not give in. ${ }^{28}$

\section{ECONOMIC DECLINE AND HUMAN RIGHTS ABUSES}

In light of Guatemala's deteriorating economic situation, the corruption and human rights abuses did not bode well for the military. Military government remained unable to provide solutions to economic crisis or to stop the decline. Low prices in the early to mid-eighties for Guatemala's agricultural exports added to the debt problem, caused by public sector (military) borrowing. ${ }^{29}$ The rising debt was not arrested until 1988, and the amount required to service the debt climbed as well (see TABLE 4). Guatemala's Gross

${ }^{27}$ Robert H. Trudeau, "The Guatemalan Election of 1985: Prospects for Democracy," in Elections and Democracy in Central America, eds. John A Booth and Mitchell A. Seligson (Chapel Hill: University of North Carolina Press, 1989), 99; and Lernoux, 556, 558 . 56-57.

${ }^{28}$ Gleijeses, "Guatemala" (1990), B269; and Barry, 37-39,

${ }^{29}$ Bowen, "Prospects for Liberalization," 46-47; James Painter, "Guatemala in Civilian Garb," Third World Quarterly 8 no. 3 (July 1986): 827. 
Domestic Product declined during this period also. ${ }^{30}$ BY 1986, more than half of Guatemala's export earnings were required to make payments on the national debt. Along with this Guatemala faced other economic woes, a decline in tourism, increasing unemployment, and a falling currency, the quetzal. 31

TABLE 4

SELECTED ECONOMIC DATA FOR GUATEMALA

\begin{tabular}{|c|c|c|c|}
\hline & $\begin{array}{c}\text { Total } \\
\text { GDP } \\
\text { (growth } \\
\text { rates) }\end{array}$ & $\begin{array}{c}\text { Total external } \\
\text { disbursed debt } \\
\text { (millions of } \\
\text { dollars) }\end{array}$ & $\begin{array}{c}\text { Debt service } \\
\text { paid } \\
\text { (long-term) } \\
\text { (millions of } \\
\text { dollars) }\end{array}$ \\
\hline 1980 & 3.7 & 1165.8 & 137.2 \\
\hline 1981 & 0.7 & 1264.2 & 128.1 \\
\hline 1982 & -3.5 & 1537.3 & 135.4 \\
\hline 1983 & -2.6 & 1799.4 & 177.5 \\
\hline 1984 & 0.5 & 2343.0 & 256.9 \\
\hline 1985 & -0.6 & 2616.9 & 268.3 \\
\hline 1986 & 0.1 & 2755.2 & 293.9 \\
\hline 1987 & 3.5 & 2816.2 & 303.2 \\
\hline 1988 & 3.7 & 2632.5 & 358.8 \\
\hline 1989 & 4.0 & 2665.0 & 378.0 \\
\hline estimate & & & \\
\hline
\end{tabular}

Source: Inter-American Development Bank, Economic and Social progress in Latin America 1990 Report (Baltimore: Johns Hopkins University Press, 1990), 114.

${ }^{30}$ Inter-American Development Bank, Economic and Social progress in Latin America 1990 Report (Baltimore: Johns Hopkins University Press, 1990), 114.

${ }^{31}$ Bowen, "Prospects for Liberalization," 46-47. 
Economic decline added to the opposition of traditional economic elites to the military regime. The business elite sector in Guatemala was more powerful than its central American neighbors. The Chamber of Agriculture, Commerce, Industry and Finance (CACIF) represented business interests conflicting with military governments. The break between the dominant economic class and the military was indicative of the economic elites desire to participate directly in the government and lessen the autonomy of the military. This split led to pressures by traditional elites for transition. 32 Military expansion into the economy as entrepreneurs and owners (see below THE MILITARY AS AN ECONOMIC PLAYER) was seen as threatening to the interests of traditional economic elites, because military enterprises competed with those of the traditional elites.

Not only could the military not produce results in resolving economic crisis, the political violence stemming from the counterinsurgency war greatly contributed to, or even caused many of Guatemala's economic problems. ${ }^{33}$ The repression and violence of the military created a "wandering

${ }^{32}$ Eduardo Gamarra and A. Douglas Kincaid, "Democratization in Latin America: A Comparative Analysis of Bolivia and Guatemala," Paper presented to the annual meeting of the Southern Political Science Association (Charlotte, NC: November 5-7, 1987), 26-27, 29.

${ }^{33}$ Richard Millett, "Guatemala: Progress and Paralysis," Current History (March 1985): 111-112. 
and dislocated rural labor force," and an increasingly disruptive guerrilla force. ${ }^{34}$ A drop in the tourist trade resulted from the extreme political violence. ${ }^{35}$ Most significant is the interrelation of international isolation and economic collapse as a result of the military's human rights abuses and mismanagement of the economy.

\section{THE MILITARY PRODUCES INTERNATIONAL ISOLATION}

From 1954 to 1986, military regimes in Guatemala, including one term with a civilian president, have searched for stability and security. A constant struggle with guerrilla insurgents, and the problems this created within the military itself (See section DIVISIONS IN THE MILITARY), helped to produce coups and instability, further exacerbating economic problems. ${ }^{36}$ National elections and transfer of government to civilians in many ways are an extension of the

${ }^{34}$ Bowen, "Prospects for Liberalization," 46 .

${ }^{35} \mathrm{Millett,}$ "Progress and Paralysis," 111.

${ }^{36}$ For further discussion of Guatemala's post-1954 military governments see: George Black, Garrison Guatemala (New York: Monthly Review Press, 1984); Handy, "Resurgent Democracy," 383-408; Gordon L. Bowen, "Guatemala: The origins and Development of state Terrorism," in Revolution and Counterrevolution in Central America and the Caribbean, eds. Donald Schultz and Douglas Graham (Boulder, Co: Westview Press, 1984), 269-300; and Congress, House, committee on Foreign Affairs, Subcommittee on Western Hemisphere Affairs, United States Policy Toward Guatemala, prepared statement of Caesar D. Sereseres, 98th Cong., 1st sess., 1983, Committee Print, 25-59. 
search for stability. The transition was seen by some in the military as a long term project for future security. ${ }^{37}$ The isolation internationally is one element of the instability faced by the military prior to 1986 .

The reasons for a nominal "transition" to civilian government had become clear.

A democratically elected administration
was seen by the army as a necessary
condition for new and expanded flows of
foreign investment and bilateral and
multilateral economic aid, which were
regarded as the best way out of the
economic decline and the increasing
social polarisation, which, if it were
not at least halted, could only benefit
the left in the long term.

According to Millett, to obtain significant foreign economic aid, desperately needed in light of Guatemala's economic decline, the military must at least let there appear to exist elected civilian rule. ${ }^{39}$

\section{ROLE OF U.S. MILITARY AID}

The nose dive in Guatemala's economy necessitated large amounts of resources from outside to even begin to improve, but military economic policy and counterinsurgency tactics almost completely isolated Guatemala internationally. The

\footnotetext{
${ }^{37}$ Barry, $43-44$.

${ }^{38}$ painter, "Civilian Garb," 819.

${ }^{39}$ Richard Millett, "After the Elections," The New Republic (24 February 1986): 18 .
} 
state terrorism practiced by the military created isolation between Guatemala and the international community, significantly the U.S. Loans and international aid became increasingly vital, but unavailable to the military regime. Human rights abuses had led to the termination of U.S. police aid in 1975 and, finally, U.S. military aid in 1977.40 The impact of the cut off of U.S. military aid on the Guatemalan military is unclear. Military aid was not resumed until 1985 when Guatemala received $\$ .5$ million in U.S. dollars in assistance, with increases to $\$ 5.4 \mathrm{million}$ in 1986 and $\$ 5.5$ million in 1987 (see TABLE 5). The resumption of aid began after elections were held for a constituent assembly to draft a new constitution and prepare for the scheduled elections in 1985.41

In spite of this, some military aid from the U.S. appears to have been supplied secretly during the sanctions, and military goods were sent from Israel as well. 42 Used as a surrogate, Israel supplied military hardware, advisors and training to benefit itself (profits from sales) as much as the

${ }^{40}$ Allan Nairn, "The Guatemalan Connection," The progressive (May 1986): 20-22.

${ }^{49}$ Gleijeses, "Guatemala" (1990), B262; and James W. Wilkie and Enrique Ochoa, eds., Statistical Abstract of Latin America vol. 27 (Los Angeles: UCLA Latin American center Publications, University of California, 1989), 770.

${ }^{42}$ Nairn, 20-22. 
TABLE 5

U.S. ASSISTANCE TO GUATEMALA

\begin{tabular}{|c|c|c|c|}
\hline YEARS & $\begin{array}{l}\text { MILITARY } \\
\text { AID IN US } \\
\$ \\
\text { MILLIONS }\end{array}$ & \begin{tabular}{|l} 
TOTAL \\
ECONOMIC \\
AID IN US \\
$\$$ MILLIONS
\end{tabular} & $\begin{array}{l}\text { TOTAL } \\
\text { ECONOMIC AND } \\
\text { MILITARY AID } \\
\text { IN US \$ } \\
\text { MILLIONS }\end{array}$ \\
\hline 1966 & 1.4 & 9.0 & 10.4 \\
\hline 1967 & 2.1 & 14.1 & 16.2 \\
\hline 1968 & 1.0 & 16.5 & 17.5 \\
\hline 1969 & 2.3 & 9.1 & 11.4 \\
\hline 1970 & 1.3 & 32.2 & 33.5 \\
\hline 1971 & 6.1 & 16.7 & 22.8 \\
\hline 1972 & 1.8 & 16.6 & 18.4 \\
\hline 1973 & 3.7 & 11.9 & 15.6 \\
\hline 1974 & 1.4 & 4.7 & 6.1 \\
\hline 1975 & 2.9 & 14.1 & 17.0 \\
\hline 1976 & 2.1 & 43.5 & 45.6 \\
\hline 1977 & 0.5 & 20.8 & 21.3 \\
\hline 1978 & $\star$ & 10.6 & 10.6 \\
\hline 1979 & * & 24.7 & 24.7 \\
\hline 1980 & - & 13.0 & 13.0 \\
\hline 1981 & - & 19.0 & 19.0 \\
\hline 1982 & - & 15.5 & 15.5 \\
\hline 1983 & $\overline{-}$ & 29.7 & 29.7 \\
\hline 1984 & $=$ & 20.3 & 20.3 \\
\hline 1985 & 0.5 & 106.9 & 107.4 \\
\hline 1986 & 5.4 & 116.7 & 122.1 \\
\hline 1987 & 5.5 & 187.8 & 193.3 \\
\hline 1988 & 9.4 & 132.2 & 141.6 \\
\hline 1989 & 9.4 & 147.2 & 156.6 \\
\hline
\end{tabular}

Source: Agency for International Development, Statistics and Reports Division, U.S. Overseas Loans and Grants and Assistance from International Organizations (Washington, D.C., 1975), 46; Agency for International Development, office of Program and Information Analysis Services, Bureau for Program Policy Coordination, U.S. Overseas Loans and Grants and Assistance from International Organizations (Washington, D.C., 1978), 50; Agency for International Development, office of Planning and Budgeting, Bureau for Program and Policy Coordination, U.S. Overseas Loans and Grants and Assistance from International orqanizations (Washington, D.C., 1980), 50; Agency for International Development, office of Planning and Budgeting, Bureau for Program and Policy Coordination, U.S. overseas Loans and Grants and Assistance from International 
Organizations (Washington, D.C., 1982), 48; Agency for International Development, office of planning and Budgeting, Bureau for Program and Policy Coordination, U.S. Overseas Loans and Grants and Assistance from International organizations (Washington, D.C., 1987), 51; and Agency for International Development, office of Planning and Budgeting, Bureau for Program and Policy Coordination, U.S. Overseas Loans and Grants and Assistance from International organizations (Washington, D.C., 1990), 51 .

U.S. ${ }^{3}$ Commercial sales to the Guatemalan government and private businesses were allowed to continue during this period, although they declined. ${ }^{4}$ officially anyway, from the U.S. point of view, the Contras in Nicaragua seemed more worthy of support than the extremely violent Guatemalan military, pushed to the background by the anti-sandinista campaign. ${ }^{45}$ The U.S. was concerned that the Soviets would exert influence in Central America after gaining a foothold in Nicaragua. Policy was often designed to limit the possibility of other guerrilla movements following the example of the Sandinistas. ${ }^{46}$

Policy goals of U.S. military assistance in Guatemala

${ }^{43}$ Cheryl A. Rubenberg, "The United States, Israel, and Guatemala: Interests and conflicts," in Central America and the Middle East: The Internationalization of the crisis, ed. Damian J. Fernandez (Miami: Florida International University Press, 1990), 97, 108; and Victor Perera, "Uzi Diplomacy," Mother Jones (July 1985): 40, 43.

${ }^{44}$ General Accounting office, Military Sales: The United States Continuing Munition Supply Relationship with Guatemala GAO/NSIAD-86-31 (January 1986), 4, 8 .

${ }^{45}$ Bowen, "Prospects for Liberalization," 45.

${ }^{46}$ Sereseres, "Highlands War," 102-103. 
have included democracy, economic stabilization, equity and defeat of the leftist insurgency. Guatemala has demonstrated its independence from the U.S. in this regard. The termination of U.S. military assistance in 1977 was a mutual decision. Guatemala had rejected the aid because of human rights conditions that were seen as interfering in the country's internal affairs. ${ }^{47}$ This raises significant doubt as to the effectiveness of aid in promoting democracy. Some argue that military aid was needed by cerezo to pacify hard liners in the military, while others would say that the military will never truly give power to civilians when they are rewarded with military aid for a facade democracy. ${ }^{48}$

\section{MILITARY MISSION AND STRUCTURE}

The military in Guatemala holds a substantial degree of autonomy which has developed over time. The armed forces are composed of the army, navy and air force, but the army is dominant. Top level army decisions in general represent the view of the military as a whole. Recruits are generally the rural poor and forced to serve, while officers are from the

\section{${ }^{47} J o n a t h a n$ E. Sanford, "Guatemala: U.S. Foreign} Assistance Facts," Congressional Research Service, 11 June $1987,3,5$.

${ }^{48} \mathrm{Caleb}$ Rossiter and Bonnie Tenneriello, "Can U.S. Military Aid Really Help a Civilian President?" Christian Science Monitor, 9 June 1988, 13; and Sanford, "Foreign Assistance," 9-10. 
middle class. The military has traditionally assigned itself not only the role of security, but that of saving the nation as well, so that the responsibility felt by the armed forces extends beyond eradicating communists into all sectors of national affairs. According to the military, helping to orient the population towards a positive attitude about a democratic system, neutralizing the guerrilla threat, gaining popular support in the fight against the guerrillas, and collecting information for intelligence that may prevent potential domestic conflict are all appropriate functions. 49 The autonomy of the military from domestic elites has grown along with its economic power, which means that the military institution facing the new civilian president had definite prerogatives and an entrenched power base to control them. ${ }^{50}$

When Vinicio Cerezo took office in 1986 hopes were high that a new era of civilian control had begun. The new constitution described the nature of the military role like this, "Es único e indivisible, esencialmente professional, apolitico, obediente y no deliberante."51 ("It is unique and indivisible, essentially professional, apolitical, obedient, and does not deliberate.") In the beginning of his term,

${ }^{49}$ Ejército de Guatemala, Dirección de Asuntos Civiles, Conceptos doctrinarios de asuntos civiles, May 1988, 12, 15, 18.

${ }^{50}$ Barry, 39-44 .

${ }^{51}$ Ejército de Guatemala, 28. 
Cerezo appeared to have a limited amount of influence with the military. Cerezo installed moderate officers to positions of importance within the military, notably the office of Defense Minister. ${ }^{52}$ This Minister holds a great deal of power in the government and over the military institution as well.53 The support of the officer in this post is essential to a civilian president, without it controlling the armed forces would be difficult to impossible. In a significant step, General Jaime Hernandez Méndez was appointed to the post of Defense Minister, preventing the army's chief of staff, General Rodolfo Lobos, forced into retirement and known for his terrible human rights reputation, from assuming the post. ${ }^{54}$

Although Hernandez was an old line officer, Cerezo appointed General Hector Gramajo to the number two post, chief of staff. 55 General Hernandez was scheduled for mandatory retirement soon thereafter, setting the stage for General Hector Gramajo, the new chief of staff, to succeed Hernandez upon his retirement. Gramajo was one of the most moderate officers in the Guatemalan military, and was seen as supportive of the new constitutional system. This all took

${ }^{52}$ Sam Dillon, "Guatemala's Cerezo Wins Battle With Army," Miami Herald, 10 January 1986, in Information Service of Latin America, hereafter cited as ISLA.

${ }^{53}$ Keefe, 194 .

${ }^{54}$ Dilion, "Guatemala's Cerezo."

${ }^{55}$ Richard Millett, "Guatemala," B302. 
place quietly, and it seemed that cerezo had won an initial victory over the armed forces. ${ }^{56}$

Open conflict with the military was rare, but rumors of coup attempts were not uncommon, revealing underlying tensions. ${ }^{57}$ A more obvious manifestation was the removal of the civilian chief of police cerezo appointed early in his term, and his replacement by a colonel. Military pressure seems to have been the cause for the change, although the public excuse was that the civilian could not cut down on street crime. ${ }^{58}$ But, as planned, Hernandez was retired on January 31, 1987, and General Gramajo became the Defense Minister. ${ }^{59}$

Dissent within the military was responsible for coup attempts in 1988 and 1989 (to be discussed further below). They were possibly aimed as much at Defense Minister Gramajo as at President Cerezo, because Gramajo was seen as more moderate than some in the military would like. The harder line military officers saw Gramajo's relationship with Cerezo as too close. At the time, Gramajo was able to easily put

${ }^{56}$ Dillon, "Guatemala's Cerezo."

${ }^{57}$ Millett, "Guatemala," B302-B303.

${ }^{58}$ Williams, "Guatemalan's 'Honeymoon'."

${ }^{59}$ Millett, "Guatemala," B303. 
down the coup attempts, but the tensions ran deep. 60

The splits in the military were not over whether they should control society, but what methods were to be used. By late 1989, after the two coup attempts, the hard line seemed to be gaining control, favoring repression as a response to popular groups. 61 In May 1990, Gramajo retired, and General Juan Leonel Bolaños (hard line) was named Defense Minister. General Juan Josë Marroquin was named chief of staff, and General Roberto Matta became deputy chief of staff. There was some resistance to the appointments, but they proceeded. The military seemed to have consolidated a hard line position, and Guatemala experienced a surge of violence. 62

Very soon, though, General Marroquin retired, and General Matta moved up to the chief of staff position, likely to be the next Defense Minister. Matta was Iinked to Gramajo's faction of the military, and so there was hope that the moderates still had influence within the military. Until another shift, though, the military was leaning towards a hard

${ }^{60}$ Lee Hockstader, "Guatemala Puts Down Coup Attempt," Washington Post, 10 May 1989, in ISLA.

${ }^{61}$ Robert H. Trudeau, "Guatemala" in Latin American and Caribbean Contemporary Record vol. 8 eds. James M. Malloy and Eduardo Gamarra (New York: Holmes and Meier, 1991), B252.

${ }^{62}$ Robert H. Trudeau, "Guatemala," to appear in Latin American and Caribbean Contemporary Record vol. 9 eds. James M. Malloy and Eduardo Gamarra (New York: Holmes and Meier, 1992). 
line. ${ }^{63}$ The changes in military office seem to reflect shifts within the military itself, rather than the amount of civilian control, although both are a part of the dynamic.

The prerogatives of the military are a little difficult to identify in this scenario. Although cerezo appeared to have some influence in the beginning, over time this became secondary to the internal workings of the military itself. In the beginning, the army seemed to have lower levels of prerogatives with regard to military appointments than in the second half of cerezo's term, but this may only reflect the interplay of the factions within the armed forces.

\section{THE MILITARY AS AN ECONOMIC PLAYER}

The military not only holds control of Guatemala through physical force, but represents a major economic player as well. In addition to personal enrichment through corruption, military officers became entrepreneurs. This enabled them to diversify into many sectors of the economy, such as hotels, housing projects, the cement industry, cattle ranching, rubber production, the national airline, telecommunications and other industrial and commercial enterprises. ${ }^{64}$ Most notable,

${ }^{63}$ Ibid.

${ }^{64}$ Trudeau, "Guatemalan Election," 96-97; and James Painter, Guatemala: False Hope, False Freedom (London: Catholic Institute for International Relations/Latin American Bureau Limited, 1987), 47-50. 
perhaps, are the army's bank, El Banco del Ejército, and the acquisition of vast tracts of land in the Northern Transversal Strip (FTN) for livestock, agriculture and forestry. ${ }^{65}$ Military control over state enterprises aided officers in enriching themselves. Public money funded the army's bank, which in turn funded the enterprises of the officers. Military leaders have also been accused of enriching themselves through arms trading. ${ }^{66}$

Another area where the military is possibly involved in corruption is drug trafficking. ${ }^{67}$ In the late 1980s, Guatemala became the major transhipment point for Colombian cocaine, as well as a leading producer of opium poppies, which are processed into heroin, mainly in Mexico. ${ }^{68}$ Guatemala is also a large producer of marijuana.69 In its 1990 report, the International Narcotics Control Board expressed concern

${ }^{65}$ Painter, False Hope, 47-50; Trudeau, "Guatemalan Election," 97; and James Dunkerley, Power in the Isthmus: A Political History of Modern Central America (London: Verso, 1988), 466-467.

${ }^{66}$ Trudeau, "Guatemalan Election," 97; Painter, False Hope, 47-50; and Barry, 41.

${ }^{67}$ CERIGUA, "'War on Drugs in Guatemala" vol. 4 (September $1990), 2,9$.

${ }^{68}$ CERIGUA, "War on Drugs," 3 ; CSUCAPAX, "Criticas por ausencia de Guatemala en la cumbre americana," Centroamerica Hoy No. 30 (5 November 1989), 17; and Lindsey Gruson, "U.S. Pinning Hopes on Guatemalan Army for stability and for War Against Drugs," New York Times, 5 July 1990, in ISLA.

69"Guerra al narcotrafico," Crónica, 8 December 1988, 2324; and "En la mira de la droga," Crónica, 4 August 1988, 12. 
over the significant increase in illegal drug cultivation, production and transhipment. ${ }^{70}$ Accusations have been made that corruption related to narcotics reaches into the highest levels of government and society. Alfonso cabrera, a presidential candidate in 1990 and close friend of Vinicio Cerezo was repeatedly implicated. ${ }^{71}$ The chief of cerezo's anti-corruption office has been incriminated through the arrests of close associates, illustrating the extensive corruption. ${ }^{72}$

The military has increasingly been connected with narcotics trafficking, in spite of its close collaboration with the U.S. in the war on drugs. The U.S. has turned to the armed forces in Guatemala as the only viable institution for help in the fight against drugs. As in other Latin American countries, in turning to the military, the U.S. may be helping to create a new mission for the armed forces. In the $1960 \mathrm{~s}$ and 1970s, the focus of the military mission centered on

${ }^{70}$ United Nations, International Narcotics Control Board, Report of the International Narcotics Control Board for 1990, 37 .

"CERIGUA, "War on Drugs," 9; "Amapola, lindisima amapola," Crónica, 28 July 1989, 15-16; Kenneth Freed, "Guatemala Seen Slipping into a Haven for Drugs," Los Angeles Times, 30 August 1989, in ISLA; Lindsey Gruson, "Finding a Lush Home in Guatemala Drug Trafficking and Poppy Growing," New York Times, 1 October 1989, in ISLA; and Robert $H$. Trudeau, "Guatemala," (1992).

${ }^{72}$ Freed, "Haven for Drugs;" and John Mcclintock, "Colombians Turn to Guatemala for Cocaine Smuggling," Miami Herald, 23 November 1989, in ISLA. 
internal security. With the changing context of transition to civilian government and changing world politics, the military faced a reassessment of its central mission. If antinarcotics becomes the military's new mission, the dangers to a democratic system are evident. This would lead to increased military intelligence activity, as well as expanded roles in police activities, politics and decision-making. 73

Repeated claims have also been made linking drug trafficking with guerrilla groups inside Guatemala. ${ }^{74}$ The validity of these accusations is questionable and is denied by URNG leaders. No conclusive evidence exists. This allows the Guatemalan military to pursue counter-insurgency with us help under the guise of fighting a war on drugs. ${ }^{75}$ In turning to the military, the U.S. dependence on army intelligence may have increased the opportunity for corruption in the military, with involvement in operations dealing with cocaine money. The military may become more corrupt with advantages collaboration with the U.S. provides. In spite of this, the

${ }^{73}$ Louis W. Goodman and Johanna S.R. Mendelson, "The Threat of New Missions: Latin American Militaries and the Drug War," in The Military and Democracy: The Future of Civil-Military Relations in Latin America, eds. Louis $W$. Goodman, Johanna S.R. Mendelson and Juan Rial (Lexington, MA: Lexington Books, 1990), 189-193.

${ }^{74}$ Congress, House, Committee on Foreign Affairs, U.S. Narcotics Control Programs Overseas: A Continuing Assessment, looth Cong., 1st sess., 1987, Committee Print, 5; and "Lindisima amapola," 15.

${ }^{75}$ CERIGUA, "War on Drugs," $2,6$. 
U.S. claims that although some military officers may be involved in illegal drug trafficking, the institution as a whole is not. ${ }^{76}$ Commanders of certain remote or border zones may be particularly susceptible to corruption. 77 For example, ten drug smugglers were arrested in 1990. Their leader, Colonel Marco Antonio Lopez, was second in command of the Quiche army base. ${ }^{78}$ It is reported that colombian traffickers pay $\$ 50,000$ for each flight which stops at a Guatemalan airfield en route to the United States. ${ }^{79}$

The occasion for graft in the area of narcotics trafficking for the Guatemalan armed forces appears to be wide open, aided by the special relationship in this area between the U.S. and the Guatemalan military, ie. U.S. reliance on Guatemalan military intelligence and cooperation. The army's special role in the economic life of the country, as well as possible and continued involvement in drug production and transhipment, gives added incentive for the military to protect its autonomy and its control of the countryside (used for clandestine transhipment and production).

${ }^{76}$ Colum Lynch, "U.S.: Guatemala Army Must Fight Drug War," Miami Herald, 30 April 1990, in ISLA; Gruson, "Pinning Hopes;" and Trudeau, "Guatemala," (1992).

7Freed, "Haven for Drugs."

${ }^{78}$ CERIGUA, "War on Drugs," $6,9$.

${ }^{79}$ David Adams, "U.S. Intensifies war on Drugs in Guatemala," Miami Herald, $10 \mathrm{July} \mathrm{1989,} \mathrm{in} \mathrm{ISLA;} \mathrm{and} \mathrm{CERIGUA,}$ "War on Drugs," 10. 


\section{DIVISIONS IN THE MILITARY}

As mentioned above the military and its officers are prominent economic players in Guatemala, but not all military personnel benefitted equally. The greediness of officers based in Guatemala City, where more opportunities for graft existed, caused discontent among junior officers in the rural areas. ${ }^{80}$ In addition, these junior officers resented carrying out the costly counterinsurgency campaign while not sharing equally in the spoils. ${ }^{81}$

Divisions also existed over just what tactics were acceptable to destroy the guerrillas. ${ }^{82}$ It seems that the goals of the military were fairly uniform, but the methods caused some dispute. The necessity of removing subversives is a given, but using tactics like the scorched earth policy of eradicating peasants that could form bases of support for guerrillas caused dissent. The Guatemalan military sees itself as the guardian of the state, but also as a director of internal policy, not only that dealing with eradicating communist insurgents. Although there may be a few officers who believe in civilian rule, more often than not, they simply understand that a nominal civilian government is necessary for

${ }^{80}$ Painter, False Hope, 51.

${ }^{81}$ Barry, 44-45; and Jennifer Schirmer, "Waging war to Prevent War," The Nation, 10 April 1989, 479. 44 .

${ }^{82}$ Bowen, "Prospects for Liberalization," 44; and Barry, 
international reasons. ${ }^{83}$

So, while still dominating the bureaucracy and the state, the military can leave behind some of the details of every day issues and concentrate on counterinsurgency. The civilian leaders provide the external face Guatemala needs in the international environment. ${ }^{84}$ Although possibly overstated that, "Cerezo provides a veneer of legitimacy to the murderers - the Guatemalan army," the point cannot be entirely denied. ${ }^{85}$

A retreat from direct government could cause further debate within the military. First of all, since divisions exist over how to handle the counterinsurgency war, and the military now has more time to devote to this, greater problems may arise. Secondly, the choice to allow a civilian elected president has also presented another cause for disunion. At least one group of lower to middle officers, hard liners on the counterinsurgency issue, see the officers important in the new regime as being agents of civilian president vinicio Cerezo's party -- the Christian Democrats. To them this translates into being "instruments of the communists." 86

${ }^{83}$ Trudeau, "Guatemalan Election," 99; Painter, "Civilian Garb," 819; and Schirmer, 478-479.

\footnotetext{
${ }^{84}$ Lernoux, "Military order," 557.

${ }^{85}$ Gleijeses, "Guatemala" (1990), B266.

${ }^{86}$ Schirmer, 479.
} 
Although this group may be a minority, debate continues within the military as to the extent of the political opening, and some do believe that Defense Minister Hector Gramajo went too far in his relationship with President cerezo. ${ }^{87}$ The two coup attempts of May 1988 and May 1989 were directed as much against Defense Minister Gramajo as President Cerezo, reflecting the continuing divisions between hard and softliners within the military. ${ }^{88}$ These divisions within the military will be part of the dynamic in the relationship with the civilian government in the process of transition.

${ }^{87}$ Gleijeses, "Guatemala" (1990), B268.

${ }^{88}$ Richard Boudreaux, "Revolt in Guatemala, While Easily Quelled, Points to Wider Grievances," Los Angeles Times, 18 May 1989, in ISLA. 


\section{CHAPTER THREE}

\section{ESTABLISHING PREROGATIVES}

Before the installation of Vinicio cerezo Arévalo as president in 1986, the military already had historically established prerogatives, areas of potential conflict. Several prerogative issues can be identified: security issues, accountability for past and continuing human rights abuses by the military, control over military structure and the power to define the military's role in society. Some of these prerogatives were made very explicit by the military prior to the transition (see below), while others were less visible.

The range of security issues for which the military claimed prerogatives is large. Included in this category are a free hand to continue the counterinsurgency campaign, control of the countryside, the intelligence role of the military, and resistance to talks with the guerrillas (Guatemalan National Revolutionary Unity -- URNG). These issues are, of course, interrelated, as are the somewhat arbitrary broader categories. Human rights concerns are very closely related to security issues. The main prerogative is 
amnesty for past military violators for crimes committed during the counterinsurgency war; however, it also includes a clear-cut statement that the military is not subject to the civilian legal system or is immune. Throughout cerezo's term security forces remained free from punishment through civilian courts (to be discussed below under HUMAN RIGHTS).

The military wanted to retain control over its own structure, be free to decide its role in society, and to have power over the President in the area of military promotions. All of these prerogatives were subject to change in magnitude, contributing to a general sense of the nature of civilmilitary relations. Before examining each of these areas over the course of Cerezo's presidency, as well as indications of conflict such as coup attempts, it will be useful to point out the visible, obvious conditions imposed by the military before the transition. These conditions clearly identify several areas where the military felt it held a strong prerogative.

\section{LIMITATIONS BEFORE INAUGURATION}

Since 1966 elections in Guatemala have provided legitimacy for counterinsurgency programmes and have not announced major shifts in political power. There was little to suggest in the victory of the DCG that the 1985 elections marked a significant departure from the pattern. 1

\footnotetext{
'Painter, "Civilian Garb," 844.
} 
It is clear that the military intended to control the Guatemalan state even after a transition to elected civilian government. Vinicio Cerezo Arévalo believed that, upon taking office in 1986, he would hold 25 percent of power and end his term with 75 percent. ${ }^{2}$ Whether this was true or not, the military still called the shots. Facing this situation, Cerezo noted in his inaugural address:

Authority does not mean power. These are two very different concepts. Power must be subordinated to authority, because power without responsible authority is tyranny and many of those who preceded us apparently did not know the difference. 3

Before allowing for the installation of a civilian president, the military took measures to protect itself and limit civilian authority. Most importantly, perhaps, the military declared a general amnesty for past violators of human rights during the counterinsurgency war, firmly establishing immunity from prosecution." Thus, cerezo could

'John H. Fish, "A 'Democratic Opening' in Guatemala," The Christian Century, 11 May 1988, 470.

3Vinicio Cerezo, "Inaugural Address" (14 January 1986), in Latin American and Caribbean Contemporary Record vol. 5, ed. Abraham F. Lowenthal (New York: Holmes and Meier, 1988), C195.

${ }^{4} \mathrm{Fish}, 470-471$; and Marjorie Miller, "Families Call for Justice for Guatemala's Missing," Los Angeles Times, in ISLA. 
not prosecute military officers for political crimes. The military also legalized its control of the countryside, and provided for the establishment of the state security council, to be headed always by the army secretary of intelligence (clearly identifying control in the area of intelligence). This was designed to limit the control of civilian Cabinet members, under whose jurisdiction certain national security issues would otherwise have fallen. In return for working within these limitations, Cerezo hoped to be able to serve out his term. But, the military held the power and the political murders continued. ${ }^{5}$ In fact, as a result of the political opening with the election of cerezo, the death toll rose.6 After an initial decline at the beginning of the civilian administration, political violence rose throughout the term, and intensified at the time of the elections in late 1990.7

\section{HUMAN RIGHTS}

Although murders by the military were less than in periods before the transition, they continued after Cerezo's

\footnotetext{
${ }^{5} \mathrm{Nairn}$ and Simon, 13-14.

"Gleijeses, "Guatemala" (1990), B266.
}

7Amnesty International, "Guatemala: Amnesty International's current Human Rights concerns" AMR 34/01/91 (January 1991), 1 ; and Human Rights Watch, "Guatemala," in Human Rights Watch World Report 1990 (New York: Human Rights Watch, 1991), 170. 
inauguration. ${ }^{8}$ Academics, students, trade unionists, journalists, street children, politicians, and especially human rights activists were the principal targets as the human rights situation deteriorated throughout his administration.? Considerable deterioration, which began in 1989, persisted into 1990, as the traditional brutality continued. ${ }^{10}$ The U.S., initially supportive of the civilian administration, publicly criticized Guatemala in 1990. In March, U.S. Ambassador Thomas F. Strook was recalled to Washington for a short time as a rebuke, openly criticizing the government before he left. ${ }^{11}$ The U.S. State Department reported that the escalating violence in Guatemala was primarily a result of a lack of government authority over security forces. ${ }^{12}$ Though Defense Minister Gramajo may have been Cerezo's ally, no military consensus existed recognizing the necessity of ending the violence. Without such an understanding, Gramajo

8Dan Williams, "Guatemalan's 'Honeymoon' May Be Over," Los Angeles Times, 17 February 1987, in ISLA.

${ }^{9}$ Amnesty International, 1 ; and Human Rights watch, 170.

${ }^{10}$ Richard Millett, "Limited Hopes and Fears in Guatemala," Current History (March 1991): 127.

${ }^{11}$ Lewis H. Diuguid, "U.S. Recalls Ambassador in Rebuke to Guatemala on Human Rights," Washington Post, 8 March 1990, in ISLA; and Trudeau, "Guatemala," (1992).

${ }^{12}$ Department of State, Country Reports on Human Rights Practices for 1990 (Washington, D.C.: U.S. Government Printing office, 1991), 631. 
did not possess enough control over the military to stop the abuses. ${ }^{13}$ Military human rights abuses continued almost unchecked, and as a result, U.S. military assistance deliveries were suspended in December of $1990 .^{14}$ The historical legacy of human rights violations by the military carried on as a hard line approach seemed to be returning, a result of shifts in the military command (to be discussed below). 15

President Cerezo and his civilian government were unable to hold the military accountable for past human rights violations or continued abuses. Early in his presidency, Cerezo made a move against the police force's Department of Technical Investigations (DIT). This organization was notorious for its involvement in political murders. Both civilians and the military recognized the corrupt nature of the DIT, which lacked support within the military, or in essence allies, in the face of cerezo's action. ${ }^{16}$ on February 4, 1986, the DIT's offices were penetrated by a special police battalion, and the 600 agents of the organization were detained. Only 115 were discharged, while 1992.

${ }^{13}$ Richard Millett, phone interview by author, 16 March

${ }^{14}$ U.S. Department of State, "Country Reports," 631. ${ }^{15}$ Trudeau, "Guatemala," (1992).

${ }^{16}$ Richard Millett, phone interview by author. 
the rest were offered retraining and new positions in the police force. Although agents were fired, a precedent of prosecution was not set. ${ }^{17}$ Prosecution of DIT members would have set a precedent too similar to the prosecution of other uniformed officers, such as the military. ${ }^{18}$ In consideration of military opposition, though, it seems that cerezo discarded plans to name a civilian to head the national police, and named a retired colonel instead. ${ }^{19}$

Striking the DIT, however, was very different than censuring the military, as the following illustrates:

However infamous, the DIT was only a
subordinate organ that executed orders.
Cerezo has cured a symptom, but the
cancer remains. At the heart of the
terror apparatus, in Guatemala, is the
military, studiously preparing its lists
of victims through the army's
intelligence services (G-2). ${ }_{20}$

Although cerezo announced that he would establish a commission to investigate the fate of the disappeared, he stayed his stated course of avoiding prosecution of members of the

${ }^{17}$ Robert J. McCartney, "Guatemala's New Ruler Moves Gingerly on Rights and Economy," Washington Post, 12 March 1986, in ISLA.

${ }^{18}$ Richard Millett, phone interview by author.

${ }^{19}$ Stephen Kinzer, "Guatemalan stays in step With Army," New York Times, 11 May 1986, in ISLA.

${ }^{20}$ piero Gleijeses, "Guatemala," in Latin American and Caribbean Contemporary Record vol. 5, ed. Abraham F. Lowenthal (New York: Holmes and Meier, 1988), B310. 
military. ${ }^{21}$ The office of Human Rights ombudsman was created, but remained ineffectual, along with the Human Rights Commission. ${ }^{22}$

Under the provisions of Esquipulas II, Guatemala, along with the other Central American states, made a commitment to engage in a national dialogue, but although formally in existence, the talks held with the armed opposition accomplished little. The amnesty decreed as part of Esquipulas II applied to the military as well as the opposition. Considerable doubt as to the government's ability to ensure guerrillas safety has resulted in few guerrillas willing to lay down their arms and turn themselves in. ${ }^{23}$ The situation of conflict continued to deteriorate in 1989 and 1990 as well. 24

There was no need for the Army to contest this prerogative (human rights), because the new civilian government did just what the military wanted. The new President made it clear that decree $8-86$, the general amnesty

${ }^{21} \mathrm{Kinzer,} \mathrm{"Guatemalan} \mathrm{Stays} \mathrm{in} \mathrm{step."}$

${ }^{22}$ Trudeau, "Guatemala," B249-250.

${ }^{23}$ LASA Commission on Compliance with the Central America Peace Accord, 15 March 1988, "Extraordinary Opportunities.. - and New Risks, " in Latin American and Caribbean Contemporary Record vol. 7, eds. James M. Malloy and Eduardo Gamarra (New York: Holmes and Meier, 1990), C14, C16-17, C2930 .

${ }^{24}$ Richard Millett, "Limited Hopes," 127. 
for the military, would not be repealed. ${ }^{25}$ During cerezo's term in office, not one military officer was convicted for human rights violations. ${ }^{26}$ After the center for criminal Justice at Harvard Law School spent two years attempting to aid Guatemala in improving the administration of justice with little success, the director of the Center concluded:

It seems clear to us that the current
government of Guatemala is prepared to
tolerate the familiar, terrible forms of
violent repression--disappearances,
torture, and death--carried out by
private groups or dissident security
forces or, perhaps by the highest levels
of army intelligence. ${ }^{27}$

In the only case where police agents were convicted, the decision was later overturned, upholding a tradition of no accountability for human rights violations by security forces. ${ }^{28}$ "They are proud of their impunity: Guatemalan officers are not prosecuted for crimes against civilians. They are proud of the fear they inspire." 29

\section{${ }^{25}$ Richard Millett, "Guatemala," B303.}

${ }^{26}$ Joyce Hackel, "Guatemala Shifts Right with Choice of President," Christian Science Monitor, 8 January 1991, in ISLA.

${ }^{27}$ Philip Benjamin Heymann, "Letter to President Vinicio Cerezo," Hemisphere (Fall 1990): 9. 181.

${ }^{28}$ Amnesty International, $1 ;$ and Human Rights watch, 180${ }^{29}$ Gleijeses, "Guatemala" (1990), B267. 


\section{U.S. ROLE}

"Guatemala is a proud, independent country that dares say 'no' to the Yankees."30 In 1977, the Carter administration suspended military aid to Guatemala because of a horrible human rights record. ${ }^{31}$ The military refused the U.S. aid in anticipation of the cutoff and carter administration demands that human rights be improved, illustrating the independent, at times belligerent, attitude which continues today. ${ }^{32}$ It is reported that as a result of the U.S. aid cutoff,". . . some top military commanders here [Guatemala] gave an unexpected response: They laughed."33

Was the suspension of U.S. military aid effective in promoting a transition to civilian government in Guatemala? Many times aid is used to try to further the foreign policy goals of the donor state by influencing the recipient. An examination of what the aims of the U.S. were in withholding aid, what the outcomes were, and what part the aid actually played could help in evaluating the impact of U.S. foreign assistance on the transition. The following describes the

${ }^{30}$ piero Gleijeses, "Guatemala," (1990), B262.

${ }^{31}$ Department of state, Foreign Broadcast Information Service: Latin American Daily Report (5 August 1986), P13. Hereafter cited as FBIS.

32Perera, "Uzi Diplomacy," 40.

${ }^{33}$ Brook Larmer, "Army Flaunts Its Independence," Christian Science Monitor, in ISLA. 
goals of US foreign assistance:

The ultimate, but usually unstated, justification for all forms of foreign assistance is to gain political influence for the United States within a particular Third World country. The logic of foreign aid in this context is relatively simple: The greater the amount of U.S. economic and military aid to a Third World country, the greater that nation's willingness to comply with the foreign policy wishes of the United States. ${ }^{34}$

The problem is that aid does not work exactly in this way. Although some influence is gained for the U.S. through aid, the recipients retain a degree of independence, not necessarily proportional to the amount of aid received. Third World states have a wide range in their actions despite accepting aid from the U.S. For example, even with threats from the U.S., Guatemala would not ratify a U.S.-sponsored document condemning Nicaragua for much destabilization in the region. 35

One of the U.S. goals in Guatemala was to see a democratic government. In 1984, elections were held for a Constituent Assembly to draft a new constitution and prepare for the scheduled elections in $1985 .{ }^{36}$ Thus, Guatemala

${ }^{34}$ Doug Bandow, "Economic and Military Aid," in Intervention in the 1980s: U.S. Foreign Policy in the Third World, ed. Peter J. Schraeder (Boulder/London: Lynne Rienner Publishers, 1989), 80 .

${ }^{35}$ Ibid. , 81.

${ }^{36}$ Piero Gleijeses, "Guatemala," (1988), B299-B301. 
seemed to be moving in a promising democratic direction, with hopes for civilian rule and the curtailment of human rights abuses.

Stated U.S. goals are not always the only objective in granting assistance. The carter administration focused on promoting development issues and human rights, 37 while the Reagan White House claimed to support transition to democracy. The Reagan administration also had a much more favorable view of Guatemala than the Carter White House. Reagan was seen in Central America as meaning more direct U.S. aid, ${ }^{38}$ though the U.S. Congress still opposed military aid to Guatemala because of continued human rights abuses. ${ }^{39}$ The stated goal of the Reagan administration may have been secondary to securing stability in Guatemala. After Cerezo was inaugurated, U.S. military aid helped stabilize the system in Guatemala by helping cerezo stay in office. The assistance aided in placating the military. ${ }^{40}$

The way in which Guatemala obtained military equipment

37Dario Moreno, U.S. Policy in Central America: The Endless Debate (Miami: Florida International University Press, 1990), 23-24.

${ }^{38}$ FBIS (13 November 1984), P8.

${ }^{39}$ Gordon L. Bowen, "Guatemala: A New Form of Totalitarianism?" Commonweal, 10 February 1984, 78.

40Thomas Carothers, "The Reagan Years: The 1980s," in Exporting Democracy: The United States and Latin America Themes and Issues, ed. Abraham F. Lowenthal (Baltimore: Johns Hopkins University Press, 1991), 100-101. 
during U.S. sanctions introduces a complicating element. Some military goods were sent to Guatemala quietly, against the wishes of the U.S. Congress. While downplaying the human rights abuses of the military in Guatemala, the Reagan administration appears to have been secretly supplying military aid until the election of a civilian, vinicio Cerezo, when open military assistance could be resumed. ${ }^{41}$

Another source of military goods and advisors was Israel. Israel became Guatemala's main supplier after the carter administration cutoff. Not only did Israel supply military hardware, but training and advisors in the counterinsurgency as well. The U.S. had found a surrogate for sending aid to Guatemala, along with other Third world states. 42 It can be argued that even if the U.S. did not encourage these transfers to Guatemala, they could have been stopped. Israel is very dependent on U.S. aid, and it would be difficult for Israel to make arms sales which the U.S. disapproved of. 43 Further exerting its independence, Guatemala built a munitions factory for its Israeli-made rifles. 44

At any rate, the Guatemalans did not seem too troubled by the lack of U.S. military aid. As has been noted,

\footnotetext{
${ }^{41}$ Nairn, 20-22.

42perera, "Uzi Diplomacy," 40, 43.

${ }^{43} \mathrm{Nairn}, 22$.

${ }^{44}$ Larmer, "Flaunts Independence."
} 
'Elections are to impress the gringos,' a prosperous businessman said. 'It's the only way we can get U.S. foreign aid again. But we'll get by in any case. We have the Israelis and the Taiwanese. ${ }^{45}$

There is indication that the military did not suffer from the loss of U.S. military aid. Funds which might have gone into development projects were used to purchase military equipment, so other sectors of society suffered, not the one targeted by the U.S. ${ }^{46}$

Even after U.S. military aid was restored with elections for civilian government (see TABLE 5, Chapter TWO), relations between the two were not smooth. One area which created tensions between the two countries was Nicaragua. While the Reagan administration was actively seeking to overthrow the Sandinistas, Guatemala followed a policy of active neutrality. President Cerezo played an active and independent role in Central America, which irritated the U.S. Cerezo followed a policy involving the idea that it was possible for a democratic government to coexist with a pro-Communist regime in Central America. ${ }^{47}$ Guatemala continued its historically independent stance. With regards to Guatemalan policy on the Sandinistas it has been said:

${ }^{45}$ Victor Perera, "Chaos in the scorched Earth," The Nation, 28 January 1984, 93.

${ }^{46}$ FBIS ( 8 August 1988), 13.

${ }^{47}$ Millett, "Guatemala," B308-B311. 
It might change in the future. . at a price. As Guatemalan officers are fond of saying, there are expensive prostitutes, there are cheap prostitutes, and there are the Hondurans, who give it for nothing. If U.S. officials want their help, they must first pay-providing far more generous assistance than congress was willing to grant in 1985.48

But cerezo continued his diplomatic efforts in the region, without serious reprisals from the U.S.49 It was more important as part of the anti-sandinista campaign to be able to portray Nicaragua as the only non-democratic government in central America. For this reason, the civilian government could not be allowed to fail. 50

Some have argued that president cerezo, in playing a leading role in the central American Peace process, also attempted to gain leverage with the military in Guatemala. Measures provided for by Esquipulas II called for free and fair elections, national reconciliation, dialogue with armed opposition and respect for human rights. These provisions, if observed, would lessen military control of the political system. 51

Although the U.S. withheld military aid longer than other

${ }^{48}$ Gleijeses, "Guatemala," (1988), B307.

${ }^{49}$ Gleijeses, "Guatemala," (1990), B262.

50Millett, "Guatemala," B311.

${ }^{51}$ Dario Moreno, Struggle for Peace in Central America (Gainsville: University of Florida Presses) forthcoming. 
forms of assistance, Guatemala does not seem to have suffered enough to cause a change in policy. The U.S. saw a civilian government elected, but the prospects for a meaningful transition look grim. ${ }^{52}$ Guatemala retained an independent attitude, in spite of past sanctions. U.S. efforts at influencing Guatemala through aid were not effective.

\section{MILITARY BUDGET}

As TABLE 6 illustrates, the military budget in relation to total government expenditures rose significantly in the five years prior to the transition. In 1986 the military budget began to level out in comparative terms, but at a higher level than the beginning of the 1980s. The decline in military budget as a percentage of total government expenditures (not including foreign assistance) at first appears puzzling. It might be expected that the military would challenge the civilian government to retain high military spending levels.

As a result of general economic crisis, the Guatemalan government budget as a whole was shrinking in terms of U.S. dollar value. The value of the quetzal in relation to the dollar was allowed to float in 1986, bringing the dollar value of the budget down. In the context of a constricting budget, military expenditures in U.S. dollar value declined after the

52Millett, "Limited Hopes," 125, 127. 
TABLE 6 (see Note)

GUATEMALAN MILITARY EXPENDITURES

\begin{tabular}{|c|c|c|c|c|c|}
\hline & $\begin{array}{l}\text { MILITARY } \\
\text { EXPEND- } \\
\text { ITURE IN } \\
\text { MILLIONS } \\
\text { OF } \\
\text { QUETZALES }\end{array}$ & $\begin{array}{l}\text { TOTAL } \\
\text { GOVERNMENT } \\
\text { EXPEND- } \\
\text { ITURES IN } \\
\text { MILIIONS OF } \\
\text { QUETZALES }\end{array}$ & $\begin{array}{l}\text { MILITARY } \\
\text { EXPEND- } \\
\text { ITURE AS } \\
\text { PERCENT- } \\
\text { AGE OF } \\
\text { TOTAL }\end{array}$ & $\begin{array}{l}\text { GOVERN- } \\
\text { MENT } \\
\text { MILITARY } \\
\text { EXPEND- } \\
\text { ITURES } \\
\text { IN } \\
\text { MILLIONS } \\
\text { OF U.S. } \\
\text { DOLLARS }\end{array}$ & $\begin{array}{l}\text { U.S. } \\
\text { MILITARY } \\
\text { AID IN } \\
\text { MILLIONS } \\
\text { OF U.S. } \\
\text { DOLLARS }\end{array}$ \\
\hline 1981 & 161 & 1335.1 & $12.1 \%$ & 161 & -- \\
\hline 1982 & 208 & 1121.0 & $18.5 \%$ & 208 & -- \\
\hline 1983 & 231 & 1015.7 & $22.7 \%$ & 231 & -- \\
\hline 1984 & 270 & 1019.2 & $26.5 \%$ & 270 & -- \\
\hline 1985 & 371 & 1039.7 & $35.7 \%$ & 371 & 0.5 \\
\hline 1986 & 378 & 1663.6 & $22.7 \%$ & 201.6 & 5.4 \\
\hline 1987 & 495 & 2087.3 & $23.7 \%$ & 198 & 5.5 \\
\hline 1988 & 645 & 2530.0 & $25.5 \%$ & 246.2 & 9.4 \\
\hline 1989 & 623 & 2933.9 & $21.2 \%$ & 221.2 & 9.4 \\
\hline
\end{tabular}

Source: SIPRI Yearbook 1991: World Armaments and Disarmament (New York: Oxford University Press, 1991), 168; Banco de Guatemala, "Boletín Estadistico" (Apri1-June 1990), 32; Banco de Guatemala, "Boletín Estadistico" (October-December 1985), 32; Agency for International Development, office of Planning and Budgeting, Bureau for Program and Policy Coordination, U.S. Overseas Loans and Grants and Assistance from International Organizations (Washington, D.C.: Government Printing office, 1982), 48; Agency for International Development, office of Planning and Budgeting, Bureau for Program and Policy coordination, U.S. Overseas Loans and Grants and Assistance from International Organizations (Washington, D.C.: U.S. Government Printing Office, 1987), 51; Agency for International Development, office of Planning and Budgeting, Bureau for Program and Policy Coordination, U.S. Overseas Loans and Grants and Assistance from International organizations (Washington, D.C.: U.S. Government Printing Office, 1990), 51; International Monetary Fund, International Financial statistics 41 no.1 (January 1988), 238; and International Monetary Fund, International Financial statistics 45 no. 1 (January 1992), 258 .

Note: All figures are given in current prices. The military 
expenditures were taken from the SIPRI Yearbook, and the total government expenditure figures from the "Boletín Estadistico." The author used these figures to calculate the percentage military expenditures comprise of total expenditures. The exchange rates used to convert military expenditures from quetzales to U.S. dollars were taken from the International Monetary Fund.

transition, though as a percentage of the government budget they remained relatively stable (see TABLE 6). This decline in military spending made the need for U.S. military assistance greater. U.S. military assistance helped supplement the dollar value of the armed forces' budget. One of the goals of the Guatemalan military in allowing the transition was to access U.S. military assistance. As a result of the election of a civilian president, the U.S. once again supplied military assistance to Guatemala, beginning with a small amount in 1985 and considerable increases in the following years (see TABLE 6). Perhaps in preparation for the transition, the military appeared to pad their budget up to the time of the transition; however, this does not explain the drop in military expenditures after 1985. My argument is that the decline in government spending on the military (in U.S. dollars) reflected the overall shrinking of the entire government budget rather than civilian attempts to reduce the military's budget. In short, obvious challenges to civilian authority in the area of the budget were not evident. 


\section{SECURITY ISSUES}

Several important prerogatives are included in security issues, They are related to the military's control of the countryside mentioned above. Continuing the violence and counter-insurgency war, Civil Defense Patrols, and preventing talks between the government and URNG are facilitated by the military's monopoly on force. Although conditions improved in the beginning of cerezo's term, political murders and disappearances quickly picked up, an illustration of the military's confidence in its position. ${ }^{53}$

That the military gave up no authority to civilians in the countryside was illustrated by the presence of civil Defense Patrols. Even though the new constitution states that Civil Defense Patrols are voluntary, the rural male population was still forced to serve by the military or face possible consequences. The government failed to protect the rights of its rural citizens. ${ }^{54}$ In response to pleas from Indians that they were being conscripted into service, the government reaffirmed the constitutional premise that the patrols are voluntary, but was unwilling to take action. Without government protection, it can be dangerous for people to

${ }^{53}$ Kenneth Freed, "Rights Abuse Increase Reported in Guatemala," Los Angeles Times, 25 November 1988, in ISLA.

${ }^{54}$ Gleijeses, "Guatemala" (1990), B266. 
demand their rights in this context. ${ }^{55}$

Preventing talks between guerrilla groups, especially the URNG (Guatemalan National Revolutionary Unity), the government, and most importantly the military, has been high on the agenda. In the fall of 1986, prospects for talks with the URNG looked promising, but under pressure from the military, Cerezo reversed his position, ending chances for the moment. ${ }^{56}$ on a trip to spain, he had proposed negotiations with the guerrillas, but withdrew the offer upon his return to Guatemala. The military had published reports and pictures portraying the brutality of the insurgents and claiming that talks could not be held with such groups. ${ }^{57}$

Under the guidelines of the Central American Peace Accords, Guatemala was to hold negotiations with the armed insurgency. Some symbolic talks were held in 1988, with the military notably absent. Without military support, real progress was not made, and by late 1989, the National Dialogue structure initiated earlier that year stalled. The National Dialogue was created as a nongovernmental organization under the National Reconciliation Commission (CNR). The talks were

${ }^{55}$ Stephen Kinzer, "Guatemala: What Has Democracy Wrought?" New York Times, 26 March 1989, in ISLA.

${ }^{56} \mathrm{Millett,} \mathrm{"Guatemala,"} \mathrm{B} 304$.

${ }^{57}$ Williams, "Guatemalan's 'Honeymoon'." 
held between religious, business, and party leaders. ${ }^{58}$ Fifteen working committees were to discuss social, political and economic issues. Part of the failure of the National Dialogue was that the URNG was excluded from direct participation and the military chose to boycott the talks. ${ }^{59}$

Although talks between the URNG and popular sectors were somewhat promising, for any future talks to be meaningful, the Guatemalan military would have to soften its stance toward the rebels. In March of 1990, Arturo Isaacs, a military spokesman, stated that the armed forces would support cerezo in allowing talks with the guerrillas through the CNR without the rebels first disarming. ${ }^{60}$ But, with a change in Defense Minister in May 1990 (discussed in chapter 2), the military appeared to be moving towards a harder line with regard to the guerrillas. Popular representatives scheduled to meet with the URNG were warned by the military not to reach agreements on too many issues. The new Defense Minister, General Bolaños, stated that the Army would not negotiate with the rebels until they disarmed, and the URNG said that it would not disarm until "conditions for true democracy and peace
${ }^{58}$ Trudeau, "Guatemala" (1992).
59Trudeau, "Guatemala" (1991), B246-247.
${ }^{60}$ CSUCAPAX, "Violaciones de derechos humanos deterioran nexos con EE.UU.," Centroamerica Hoy No. 38 (23 March 1990), 3. 
exist in Guatemala."61 Although direct talks with the military were not held, meetings with other sectors in society continued. In September 1990, the URNG met with the Comite Coordinador de Asociaciones Agrícolas, Comerciales, Industriales y Financieras (CACIF) in Canada. Although no agreements were concluded, both parties gave positive evaluations of the talks aimed at finding a peaceful solution to the conflict. ${ }^{62}$

So, although some talks were held, the military effectively kept real negotiations off the agenda. The military had a strong prerogative in this area, and was willing to contest civilian authority, but fortunately not to the point of removing civilian government. Public pressure grew in Guatemala as the military was more and more seen as part of the problem and not the solution. ${ }^{63}$ The military retained a high level of prerogative in this area, and with a monopoly on force and the ability to veto direct talks between the URNG and itself, the military effectively prevented meaningful discussion with the armed opposition during the Cerezo administration.

${ }^{61}$ Ibid.

${ }^{62}$ CSUCAPAX, "Campaña electoral marcada por atentados y denuncias," Centroamerica Hoy" No. 47 (20 September 1990), 13. ${ }^{63}$ Ibid. 


\section{COUPS AND CHANGE}

Military coup attempts in May of 1988 and May of 1989 provided tangible reminders of the possibility of military intervention into politics. On May 11, 1988, two army units staged a coup attempt, which was quickly put down. Defense Minister Hector Gramajo had six officers involved arrested and three others suspended or retired.64 This may reflect that the coup was directed at Gramajo. All of the plotters were later granted amnesty. ${ }^{65}$ The coup plotters reflected sentiments of elements within the military unwilling to make serious adjustments towards civilian rule. While Gramajo still intended to preserve a great deal of military autonomy, those on the Right or Far Right saw the possible alliance between more moderate sections of the military and cerezo as threatening. Such an alliance would exclude the Far Right. ${ }^{66}$ At this point a change seemed to have occurred in Cerezo's relationship with the military. In exchange for protecting the civilian government from the plotting officers, cerezo reportedly gave up any authority he had over the military. ${ }^{67}$ After this, Cerezo's influence with the military continued to

${ }^{64} \mathrm{James}$ LeMoyne, "Guatemalan Army Arrests 6 officers Linked to Coup," New York Times, 15 May 1988, in ISLA.

${ }^{65}$ Hockstader, "Coup Attempt."

${ }^{66}$ Richard Millett, phone interview by author.

${ }^{67}$ Freed, "Rights Abuse." 
wane.

Almost a year later on May 9, 1989, another coup attempt was put down by troops loyal to the government. Again, the target was likely the moderate Defense Minister. The day of the coup attempt, cerezo and Gramajo held a joint news conference showing the solidarity between the two. Gramajo pledged support for the President, announcing that the plotters had been arrested and investigations were proceeding. ${ }^{68}$ In addition, cerezo claimed:

There is complete tranquillity and
support for the institutional process, as
is expected from the Guatemalan Army.
That is why we have said that the Army,
as an institution, has complied with its
responsibility. only a few individuals
who had already been punished for
irresponsibility or lack of
professionalism are involved. so there
is no problem. 69

Although cerezo lost much of his power in the previous coup attempt, this second incident further increased his dependence on the faction of the military committed to civilian rule. ${ }^{70}$ This reflects cerezo's accommodation and weakness in relation to the military. As an indication of Cerezo's position, some of the demands of rebel officers were met by the administration including: increased military

\footnotetext{
${ }^{68}$ FBIS (10 MaY 1989), 11-12.

${ }^{69}$ Ibid. , 12 .

${ }^{70}$ Boudreaux, "Revolt in Guatemala."
} 
spending, more political officers in key public administration positions, military control over police forces, continuing Civil Defense Patrols, and closing the political opening for the URNG. ${ }^{71}$ As after the first coup attempt, paramilitary actions and human rights violations by the army rose. ${ }^{72}$

Though Cerezo lost influence as a result of the coup attempts, it is argued that he did not do enough in the beginning of his term to try to tame the military. This is the reason for the following allegation:

'Cerezo has had less trouble with the
military than he should have had,'
comments one western diplomat
caustically. 'He's done everything but
put on a uniform, and he has less control
over the military than he might have had
because of the way he is dealing with
them. 73

This accusation, although noting a useful perspective, ignores the realities of political life in Guatemala. Cerezo apparently never expected to consolidate democratic rule, and so, did not vigorously work towards this goal. ${ }^{74}$ Perhaps viewing his term in office as a transition period was a realistic attitude under the circumstances.

${ }^{71}$ Barry, 46.

${ }^{72}$ Paul Kantz, "Guatemala's Reform Effort Is Failing," Christian Science Monitor, 23 August 1989, in ISLA.

${ }^{73}$ Peter Ford, "Guatemala Inches Forward," Christian Science Monitor, 23 June 1986, in ISLA.

${ }^{74}$ Stephen Kinzer, "Guatemalan Army Yields Little Power to Leader," New York Times, 13 May 1987, in ISLA. 
Merely completing his term can be seen as an accomplishment in itself, and any move towards democracy an even greater one, considering some views from within the military:
'Vinicio is a project of ours -- not vinicio himself, but the return of civilian institutions,' a top Guatemalan Army man said recently. This civilian project is really a military project. We can defend the country better this way. That's why we were the first to press for elections, and that's why we want this project to succeed. 175

Although the military withdrew from political office, this did not mean that any power was relinquished to civilians along with government offices. The military remained as it planned "the power behind the throne." 76

The position of Guatemala is similar to that of Brazil. With unequal civilian accommodation in prerogative areas, the military was able to prevail without much contestation. Though this identifies the pattern of Guatemala's civilmilitary relations, Guatemala cannot easily be classified as either solely democratic or authoritarian. The situation during cerezo's term was somewhat unique in Guatemala's history, including both democratic and authoritarian elements.

${ }^{75}$ Stephen Kinzer, "Walking the Tightrope in Guatemala," New York Times, 9 November 1986, in ISLA.

${ }^{76}$ Lernoux, 556. 


\section{CHAPTER FOUR}

This thesis proposed to answer the following question: How have civil-military relations determined the nature of transition towards democracy in Guatemala from 1986-1990? Using stepan's model, the research reveals that civil-military relations discouraged a full transition as defined in this thesis. As used here, a transition indicates movement from an authoritarian regime to a liberal-democratic one, meaning that ruling is based on the consent of society. Instead, the situation in Guatemala during the cerezo administration closely resembles what Alfred Stepan describes as unequal civilian accommodation, or a "civilian headed garrison state."1 The research presented here indicates that while military prerogatives were high, open military contestation was not necessary due to accommodation on the part of civilian officials. Examination of the main areas for potential conflict between the military and civilian government in the case of Guatemala, led to the conclusion that a situation of unequal civilian accommodation existed from 1986-1990.

Many issues faced the military in the period prior to

'stepan, 101. 
withdrawal from politics: economic decline and an increasing foreign debt burden illustrated the military's inability to manage the economy effectively; violence of the military government against citizens isolated Guatemala from international financial resources worsening the country's economic situation; and internal divisions within the military reflected the strains of governing, conflict over return to civilian government and methods for pursuing counterinsurgency.

The narrative presented in this thesis noted that from 1954 until 1986, with the exception of one presidential term, the military ruled Guatemala directly. The coup in 1954, which brought the military to power, aimed its violence at progressive or leftist political actors. For the next two decades, military attention focused on excluding these elements from politics. As a result, guerrilla insurgencies, such as the Guatemalan National Revolutionary Unity (URNG), developed in the highland areas. subsequent military governments devoted substantial energy to fighting these guerrilla groups, which provided a rationale for continued military rule.

In 1982, with the coming to power of General Efrain Rios Montt, the military engaged in a campaign to destroy the guerrillas. Rios Montt, a fundamentalist protestant, headed a government (1982-1983), which set about permanently altering 
the organization of the countryside. In the process, thousands were killed. Civil Defense Patrols, model villages and civic action programs were used to gain control of rural areas for the military with some success. This facilitated the transfer from military to civilian government in 1986, as it placed the military in a position of strength.

General Mejia Victores led a group of officers which overthrew Rios Montt in 1983. General Mejia reinforced military discipline and prepared for elections in 1985. Several factors prompted the military to return to the barracks. The military had been unable to halt economic decline and faced a tremendous foreign debt burden. Military human rights abuses isolated Guatemala internationally, as well as dislocating the rural work force and prompting a decline in the tourist trade. A constituent assembly drafted a constitution and held elections which were won by vinicio Cerezo Arévalo. Cerezo, a Christian Democrat, took office in 1986. At the time of the transfer, the army's strength in relation to other political actors was at its highest point.

Throughout this period, the Guatemalan military searched for security and stability. However, continued guerrilla insurgency and conflict among factions within the institution, exacerbated by the costs of governing, added to political instability. Groups within the military saw a return to civilian government as a long-term project for stability. 
Civilian government would bring increased amounts of military and economic assistance, and allow the military to preserve unity. Involvement in politics had caused increased factionalism within the military, and returning to the barracks meant preserving institutional cohesion. Returning to the barracks, however, did not mean surrendering power, as the military retained the capacity to influence the political system.

At the time of the transition from military to civilian government in 1986, the military held a set of established prerogatives. A prerogative exists when the military believes it has the right to control an issue. Contestation involves open articulated conflict with civilian authorities over these issues or prerogatives. Prerogative areas in Guatemala at the time of military withdrawal included: amnesty for past human rights violations by the military; the military budget; control over military mission and structure, domination of the countryside; and pursuit of counterinsurgency campaigns. The latter two were aided by United States military assistance, which helped the Guatemalan military develop an effective internal security capacity. In 1977, the U.S. suspended military aid to Guatemala in an effort to promote a transition to civilian government, though, in my view, the suspension of aid was not the deciding factor in bringing about the transition. U.S. pressure was secondary to the internal 
dynamics of Guatemala and the Guatemalan military.

The time the military spent in politics exacerbated tensions within the armed forces. Divisions over opportunities for graft, techniques for pursuing counterinsurgency, and the transition itself were important concerns. The military found ruling more difficult than it had anticipated, and governing distorted military functions. Withdrawal to the barracks served in some ways to preserve military unity, but with elected civilian government and the absence of a significant guerrilla threat, the military was forced to reevaluate its central mission.

This thesis has documented that the internal dynamics of the military affected civil-military relations from 1986-1990. Coup attempts in 1988 and 1989 provided evidence of factional tensions within the military and dissatisfaction with civilian government. To ward threats from the Right, President cerezo became dependent upon moderate sectors of the military for support. This left cerezo without much basis to challenge military prerogatives, as evidenced by the lack of contestation. As stepan discussed, high levels of military prerogatives and low levels of contestation indicate a situation of unequal civilian accommodation, or as described here, a civilian government unable to challenge strong military prerogatives.

open contestation between the military and civilian 
government was rare. Military human rights abuses, for example, continued after cerezo took office. Although Cerezo created the office of Human Rights Ombudsman and the Human Rights Commission, conditions deteriorated in 1989 and 1990. In other words, civilian inquiries into past human rights abuses did not prevent continued abuses or declare responsibility for previous violations. A clear indication of military strength in a prerogative area (no accountability for human rights abuses committed by the military) was President Cerezo's declaration that he would not repeal decree 8-86 which granted amnesty to the military for past human rights violations. At the end of cerezo's term, no military officers had been convicted of human rights abuses. In short, contestation by the Guatemalan armed forces was minimal owing to the cerezo government's accommodation.

This thesis also noted that under the guidelines of Esquipulas II, negotiations between the government and the guerrillas were to be held. Meaningful talks with the Guatemalan National Revolutionary Unity (URNG) were prevented by the military. Instead, continuing counterinsurgency efforts led to further abuses by the military. One measure to control the countryside, forced participation in Civil Defense Patrols, remained problematic, despite the constitution's stipulation for voluntary patrols. Indians complained to the government of conscripted service. The government, however, 
took no action. The war on drugs promoted by the U.S. could represent a new mission for the armed forces in Guatemala and was used as an excuse for continued military dominance in the countryside. Because the military defined control of the countryside and freedom to continue counterinsurgency campaigns as key prerogatives, the cerezo government did not challenge the armed forces in these areas.

As noted in this thesis, contestation was not evident over the military budget. As a percentage of government expenditures, the military budget declined in relation to the years prior to the transition, but leveled out at a percentage higher than that of the early 1980s. The decline in actual value of military spending reflected the shrinking of the government budget as a whole. My argument suggests that the decrease reflects constricting government resources rather than attempts by the civilian government to reduce the military's budget. Thus, access to U.S. military assistance became more important to supplement military spending.

The cerezo government faced two coup attempts which were easily put down. They reflected tensions within the armed forces and were aimed both at moderate Defense Minister Gramajo and cerezo. The coup attempts represented the sentiments of factions of the military left out by a new alliance between moderate elements in the military, represented by Gramajo, and civilians. Notably, the extreme 
Right was excluded and plotted to retain its own set of prerogatives. Defense Minister Gramajo achieved a high level of autonomy for the armed forces by negotiating with these forces. As a result, cerezo became dependent on Gramajo and his faction of the military for support.

The high levels of prerogatives and low levels of contestation indicate that unequal civilian accommodation was the pattern of civil-military relations in Guatemala during the cerezo administration. The military continued to play an important role in national politics. The civilian government had to contend with the veto power of the military over policymaking. As a result, the military was able to control issues about which it was concerned without holding office. Cerezo's dependence on Gramajo's faction within the armed forces further weakened his government's ability to act autonomously.

Stepan's model proved useful in a comparative setting. The areas for examination were relevant to the Guatemalan case, and provided a gauge of civil-military relations during the Cerezo administration. Using this model, the prospects for democratization appear grim. Even though the model devised by stepan is dynamic, allowing for change, including further democratization, this was not the case in Guatemala from 1986-1990. Though democratization was not the result of the transfer from military to civilian government, a change 
did occur. Perhaps what may better describe the situation is a legitimation of military rule through civilian government and institutions.

The situation of Guatemala from 1986-1990 is not unique and represents broader issues of civil-military relations in Latin America. Other Latin American states have had similar experiences. With the latest wave of transitions from authoritarian rule, democracy has had significant ideological value in Latin America, but with limited results. Guillermo O'Donnell describes the problem as follows:

positive evaluation pointed out that
democracy per se and, especially, the
fear of relapsing into authoritarian
rule, may make democratic leaders
excessively cautious on some crucial
issues. These include how civilian
governments select and implement policies
aimed at alleviating the more pressing
inequalities of their countries, and how
they maneuver the armed forces into a
situation of reasonably effective
subordination to their authority.
Excessive caution in these domains may
facilitate the transition to limited
democracy (democraduras), but for the
same reason it is likely to generate
regimes too weak and too devoid of
popular support to be viable in the
medium and long run. ${ }^{2}$

Stepan's classification of unequal civilian accommodation,

${ }^{2}$ Guillermo O'Donnell, "Introduction to the Latin American Cases," in Transitions from Authoritarian Rule: Latin America, eds. Guillermo O'Donnell, Philippe C. Schmitter and Laurence Whitehead (Baltimore: Johns Hopkins University Press, 1986), 17. 
with civilians proceeding in an excessively cautious manner, resembles this concept of a limited democracy.

Too often the two extremes, democracy and authoritarianism, are discussed without the possibility of a combination including elements of both, what might be called a "hybrid" or O'Donnell's democradura. That Latin America oscillated between cycles of authoritarian rule and democracy was held as common wisdom. To better understand the latest wave of transitions, more refined typologies are needed to describe regimes that are part free and democratic and part authoritarian. In some cases, democratic institutions may only provide a mask for authoritarian politics. One reason for discussing and identifying hybrids is to allow for equilibrium or stability of a regime type between the extremes of authoritarianism and democracy. ${ }^{3}$

Edelberto Torres-Rivas discusses hybrids in a slightly different terms. He describes the recent changes in central American politics as possible democracy. The possible democracy, while still relying on authoritarian elements, differs from the despotism of previous years in which popular access to participation and power were not imaginable.

${ }^{3}$ James M. Malloy, "The Politics of Transition in Latin America," in Authoritarians and Democrats: Regime Transition in Latin America, eds. James M. Malloy and Mitchell A. Seligson (Pittsburgh: University of Pittsburgh Press, 1987), $236,256-257$; and Lucien $W$. Pye, "Political Science and the Crisis of Authoritarianism," American Political Science Review 84 no. 1 (March 1990): 13. 
Authoritarian elements and the possibility of democracy together form the possible democracy. The possible democracy in Central America combines persistent authoritarianism with a new type of organization of political life. The key in forming a possible democracy is the foundation of a democratic method of government. That democracy is seen as an attainable goal accounts for changes towards possible democracy. ${ }^{4}$

James M. Malloy addresses the issue of hybrids more directly. The process of transition in Latin America in the 1980 s represents movement towards types of hybrid regimes. Malloy in essence describes two types or manifestations of hybrid regimes. In the first, democracy, in an electoral sense, is combined with an authoritarian style of governance. According to Malloy, this type of authoritarian decision making is prevalent where executives must implement economic austerity programs. Policy making in this way does not favor the type of bargaining among options associated with a liberal democratic system. A second variation of hybrid form would be civilian governments fronting authoritarian regimes in which the military dominates a civil-military pact. ${ }^{5}$

"Edelberto Torres-Rivas, Repression and Resistance: The Struggle for Democracy in Central America (Boulder: Westview Press, 1989), 143, 150-151.

5James M. Malloy, "Economic Crisis and Democratization: Latin America in the 1980s", in Lat in American and Caribbean Contemporary Record vol. 8, eds. James M. Malloy and Eduardo Gamarra (New York: Holmes and Meier, 1991), 149-150. 
James M. Malloy and Eduardo A. Gamarra describe Bolivia during the administration of President Victor Paz Estenssoro from 1985-1989 as the first type of hybrid identified above.6 In order to deal with the economic situation and manage austerity, Paz Estenssoro resorted to authoritarian decision making. ${ }^{7}$ As a result of a pact between the major political parties, decisions made by the executive or a few top decision-makers were legitimated by the legislature. Rather than functioning as a law making body, the legislature legitimated executive decisions. Malloy and Gamarra argue that this may evolve into a hybrid regime where the executive holds authoritarian decision making power while the legislature serves to legitimate the system. ${ }^{8}$

Guatemala represents the second type of hybrid regime. Even though elections were held, the guerrilla insurgency weakened and a transfer to civilian government took place, Edelberto Torres-Rivas describes the situation in Guatemala as one in which the military retained power. The civilian government was reduced to public administration, while the military made significant decisions. Though the military continued to dominate the political system, Torres-Rivas

'James M. Malloy and Eduardo Gamarra, Revolution and Reaction (New Brunswick: Transaction Books, 1988), 226.

7Malloy, "Economic Crisis," 149.

${ }^{8} \mathrm{Malloy}$ and Gamarra, 226. 
suggests that this may be the central American way of affecting a transition. ${ }^{9}$ Torres-Rivas description of Guatemala during the cerezo administration resembles the "hybrid" model described by Malloy in which civilians, through elections, provide a facade of legitimacy for the military. Formal democratic institutions existed, while the military exercised authoritarian power.

This second type of hybrid regime may also be seen in Peru. Since Alberto Fujimori assumed the Presidency of Peru in 1990, he has often ruled by decree, bypassing the legislature. In the chaotic context of Peruvian politics, with political violence from both the Shining Path and the military, Peru can be seen as a democradura. Though the formal institutions of democracy exist, the violent climate leads to a vital role for the military. ${ }^{10}$ The situation in Peru has been termed Fujiborización", referring to past events in Uruguay.

During the administration of Jose Maria Bordaberry in Uruguay, the military accused senators and deputies of

${ }^{9}$ Edelberto Torres-Rivas, Centroamérica: La Democracia posible (Editorial Universitaria Centroamericana, 1987), 174.

${ }^{10}$ Francisco Durand, "Peru: Political stalemate in the Time of Cholera," Paper presented at the Conference Democracia, Mercados y Reformas Estructurales en America Latina (Buenos Aires: March 25-27, 1992).

"Carlos Monje, Lecture, Florida International University, Miami, Florida, February 2, 1992. 
corruption and links to terrorist organizations. As a result, the military began to believe that they could promote development and prevent subversion better than the President. When it became obvious that Bordaberry could not beat the military, he joined them. The military had refused his choice of Defense Minister and the National Assembly would not revoke a Senator's immunity from prosecution for terrorist links. In response, Bordaberry closed the National Assembly and headed a military dominated regime. ${ }^{12}$ Thus, the term Fujiborización is based in the similar problems of ruling in Peru and Uruguay.

The situation of a hybrid regime does not represent a full transition to democracy, and possibly does not indicate that further Iiberalization is on the way. What the case of Guatemala and others may point to is a new equilibrium in the political systems of Latin American states, somewhere between authoritarianism and democracy. In the Guatemalan case, the military affects policy through civilian government. If the military refrains from direct intervention into politics, this "hybrid" system has the potential to remain stable for some time.

The identification of Guatemala as the second type of

${ }^{12}$ Charles G. Gillespie, "Uruguay's Transition from Collegial Military-Technocratic Rule," in Transitions from Authoritarian Rule: Latin America, eds. Guillermo o'Donnell, Philippe Schmitter and Laurence Whitehead (Baltimore: Johns Hopkins University Press, 1986), 175-176. 
hybrid discussed in this chapter provides a confirmation of the validity of stepan's model. The hybrid is in essence Stepan's unequal civilian accommodation. Both terms refer to military dominated regimes with weak civilian authority and formal democratic institutions. Thus, stepan's model was useful in identifying the nature of civil-military relations in Guatemala during the cerezo administration.

If the situation changes in the future, stepan's model provides an explanation. The model is not static and explains shifts based on differing levels of prerogatives and contestation. A shift to a harder line within the military, for example, could lead to higher levels or more extensive prerogatives. This could make it more difficult for civilian government to avoid challenging these prerogatives, leading to increased contestation. Such shifts can be discussed using Stepan's model, allowing a reassessment of a case over time.

As in Guatemala, other Latin American states may experience this type of "hybrid democratization." Though these systems may not represent democracy in the traditional liberal democratic sense, a type of government, with many variations, may be evolving and represent the opportunity for stability of regime type. This realization is useful in evaluating Latin American transitions, as it provides for a more realistic goal upon which to judge progress away from authoritarianism. 
WORKS CITED

Adams, David. "U.S. Intensifies War on Drugs in Guatemala." Miami Herald, 10 July 1989, in ISLA.

Agency for International Development. Development, Statistics and Reports Division. U.S. Overseas Loans and Grants and Assistance from International organizations. Washington, D.C.: U.S. Government Printing office, 1975.

Agency for International Development. Office of Program and Information Analysis Services. Bureau for Program and Policy Coordination. U.S. Overseas Loans and Grants and Assistance from International organizations. Washington, D.C.: U.S. Government Printing Office, 1978.

Agency for International Development. Office of Planning and Budgeting. Bureau for Program and Policy Coordination. U.S. Overseas Loans and Grants and Assistance from International organizations. Washington, D.C.: U.S. Government Printing office, 1980.

Agency for International Development. Office of Planning and Budgeting. Bureau for Program and Policy Coordination. U.S. Overseas Loans and Grants and Assistance from International organizations. Washington, D.C.: U.S. Government Printing office, 1982 .

Agency for International Development. Office of Planning and Budgeting. Bureau for Program and Policy Coordination. U.S. Overseas Loans and Grants and Assistance from International organizations. Washington, D.C.: U.S. Government Printing office, 1987.

Agency for International Development. Office of Planning and Budgeting. Bureau for Program and Policy coordination. U.S. Overseas Loans and Grants and Assistance from International orqanizations. Washington, D.C.: U.S. Government Printing office, 1990. 
Aguilera, Gabriel. "The Armed Forces, Democracy, and Transition in Central America," In The Military and Democracy: The Future of Civil-Military Relations in Latin America, eds. Louis $W$. Goodman, Johanna S. R. Mendelson, and Juan Rial, 23-38. Lexington: Lexington Books, 1990.

"Amapola, lindisima amapola." Crönica, 28 July 1989, 11-17.

Amnesty International. "Guatemala: Amnesty International's current Human Rights Concerns." AMR 34/01/91 (January 1991).

Banco de Guatemala. Boletín Estadístico. October-December 1985 .

--.--. Boletin Estadístico. April-June 1990.

Bandow, Doug. "Economic and Military Aid," In Intervention in the 1980s: U.S. Foreign Policy in the Third World, ed. Peter J. Schraeder, 63-83. Boulder/London: Lynne Rienner Publishers, 1989.

Barry, Tom. Guatemala: A Country Guide. Albuquerque: The Inter-Hemispheric Education Resource Center, 1989.

Black, George. Garrison Guatemala. New York: Monthly review Press, 1984.

Black, Jan Knippers. Sentinels of the Empire: The United States and Latin American Militarism. New York: Greenwood Press, 1986.

Booth, John A. and Thomas W. Walker. Understanding Central America. Boulder: Westview Press, 1989.

Boudreaux, Richard. "Revolt in Guatemala, While Easily Quelled, Points to Wider Grievances." Los Angeles Times, 18 May 1989, in ISLA.

Bowen, Gordon L. "Guatemala: The Origins and Development of state Terrorism," In Revolution and counterrevolution in Central America and the Caribbean, eds. Donald Schultz and Douglas Graham, 269-300. Boulder, CO: Westview Press, 1984 .

-.-.-.. "Guatemala: A New Form of Totalitarianism?" Commomweal (10 February 1984): 76-78 
"Prospects for Liberalization by way of Democratization in Guatemala," In Liberalization and Redemocratization in Latin America, eds. George A. Lopez and Michael Stohl, 33-55. New York: Greenwood Press, 1987 .

Calvert, Peter. Guatemala: A Nation ion Turmoil. Boulder: Westview Press, 1985.

Carothers, Thomas. "The Reagan Years: The 1980s," In Exporting Democracy: The United States and Lat in America Themes and Issues, ed. Abraham F. Lowenthal, 90-122. Baltimore: Johns Hopkins University Press, 1991.

Cerezo, Vinicio. "Inaugural Address" (14 January 1986), In Lat in American and Caribbean Contemporary Record vol. 5 , ed. Abraham F. Lowenthal, C192-C196. New York: Holmes and Meier, 1988.

CERIGUA. "War on Drugs on Guatemala." vol. 4, September 1990.

Chalmers, Douglas A. and Craig H. Robinson. "Why Power Contenders Choose Liberalization." International studies Quarterly 26 no. 1 (March 1982): 3-36.

CSUCAPAX. "Criticas por ausencia de Guatemala en la cumbre americana." Centroamerica Hoy No. 30 (5 November 1989), 16-18.

--n---. "Violaciones de derechos humanos deterioran nexos con EE.UU." Centroamerica HoY No. 38 (23 March 1990), 13 .

"Campana electoral marcada por atentados y denuncias." Centroamerica Hoy No. 47 (20 September 1990), 12-14.

Dahl, Robert. Polyarchy. New Haven: Yale University Press, 1971.

Dillon, Sam. "Guatemala's Cerezo wins Battle With Army." Miami Herald, 10 January 1986, in ISLA.

Diuguid, Lewis. "U.S. Recalls Ambassador in rebuke to Guatemala on Human Rights." Washington Post, 8 March 1990 , in ISLA.

Dunkerley, James. Power in the Isthmus: A Political History of Modern Central America. London: Verso, 1988. 
Durand, Francisco. "Peru: Political stalemate in the Time of Cholera," Paper presented at the conference Democracia, Mercados y Reformas Estructurales en America Latina. Buenos Aires, 25-27 March 1992.

Ejército de Guatemala, Dirección de Asuntos Civiles. conceptos doctrinarios de asuntos civiles. May 1988.

"En la mira de la droga." Crónica, 4 August 1988, 11-14.

Fish, John. "A 'Democratic Opening' in Guatemala." The Christian Century (11 May 1988): 470-471.

Ford, Peter. "Guatemala Inches Forward." Christian Science Monitor, 23 June 1986, in ISLA.

Freed, Kenneth. "Rights Abuse Increase Reported in Guatemala." Los Angeles Times, 25 November 1988, in ISLA.

---.-. "Guatemala seen Slipping into a Haven for Drugs." Los Angeles Times, 30 August 1989, in ISLA.

Gamarra, Eduardo and A. Douglas Kincaid. "Democratization in Latin America: A Comparative Analysis of Bolivia and Guatemala," Paper presented to the annual meeting of the Southern Political Science Association. Charlotte, NC, 5-7 November 1987.

Gillispie, Charles G. "Uruguay's Transition from Collegial Military Technocratic Rule," In Transitions from Authoritarian Rule: Latin America, eds. Guillermo O'Donnell, Philippe schmitter and Laurence Whitehead, 173-195. Baltimore: Johns Hopkins University Press, 1986.

Gleijeses, Piero. "Guatemala," In Latin American and Caribbean Contemporary Record vol. 5, ed. Abraham F. Lowenthal, B299-B312. New York: Holmes and Meier, 1988.

"Guatemala," In Latin American and Caribbean Contemporary Record vol. 7, eds. James M. Malloy and Eduardo Gamarra, B259-B274. New York: Holmes and Meier, 1990 . 
Goodman, Louis W. and Johanna S.R. Mendelson. "The Threat of New Missions: Latin American Militaries and the Drug War," In The Military and Democracy: The Future of Civil-Military Relations in Latin America, eds. Louis W. Goodman, Johanna S.R. Mendelson and Juan Rial. Lexington, MA: Lexington Books, 1990.

Gruson, Lindsey. "Finding a Lush Home in Guatemala Drug Trafficking and Poppy Growing." New York Times, 1 October 1989, in ISLA.

"U.S. Pinning Hopes on Guatemalan Army for Stability and for War Against Drugs." New York Times, 5 JulY 1990, in ISLA.

"Guerra al narcotráfico." Crónica, 8 December 1988, 23-24.

Hacke1, Joyce. "Guatemala shifts Right with choice of President." Christian Science Monitor, 8 January 1991, in ISLA.

Handy, Jim. "Resurgent Democracy and the Guatemalan Military." Journal of Latin American studies 18 no. 2 (November 1986): 383-408.

-----. "The Most Precious Fruit of the Revolution': The Guatemalan Agrarian Reform, 1952-54." Hispanic American Historical Review 68 no. 4 (November 1988): 675-705.

Heymann, Philip Benjamin. "Letter to President Vinicio Cerezo." Hemisphere (Fall 1990): 8-9.

Hockstader, Lee. "Guatemala Puts Down Coup Attempt." Washington Post, 10 May 1989, in ISLA.

Human Rights Watch. "Guatemala," In Human Rights Watch World Report 1990, 170-189. New York: Human Rights Watch, 1991.

Huntington, samuel. Political order in changing societies. New Haven: Yale University Press, 1968.

Inter-American Development Bank. Economic and Social Progress in Latin America 1990 Report. Baltimore: Johns Hopkins University Press, 1990.

International Monetary Fund. International Financial Statistics 41 no. 1. January 1988. 
International Monetary Fund. International Financial Statistics 45 no. 1 . January 1992.

Janowitz, Morris. The Military in the political Development of New Nations. Chicago: University of Chicago Press, 1964 .

Kantz, Paul. "Guatemala's Reform Effort Is Failing." Christian Science Monitor, 23 August 1989, in ISLA.

Keefe, Eugene K. "National Security," In Guatemala: A Country Study, ed. Richard F. Nyrop, 177-217. Washington, D.C.: U.S. Government Printing Office, 1983.

Kinzer, Stephen. "Guatemalan Stays in step With Army." New York Times, 11 May 1986, in ISLA.

-.--. "Walking the Tightrope in Guatemala." New York Times, 9 November 1986, in ISLA.

---.-. "Guatemalan Army Yields Little Power to Leader." New York Times, 13 May 1987, in ISLA.

-.-.. "Guatemala: What Has Democracy Wrought?" New York Times, 26 March 1989, in ISLA.

Larmer, Brook. "Army Flaunts Its Independence." Christian Science Monitor, 27 February 1989, in ISLA.

LASA Commission on Compliance with the Central America Peace Accord, 15 March 1988. "Extraordinary opportunities . - and New Risks," In Latin American and Caribbean Contemporary Record vol. 7, eds. James M. Malloy and Eduardo Gamarra, C13-C59. New York: Holmes and Meier, 1990 .

LeMoyne, James. "Guatemalan Army Arrests 6 officers Linked to Coup." New York Times, 15 May 1988, in ISLA.

Lernoux, Penny. "Guatemala's New Military Order." The Nation (28 November 1988): 556-560.

Lopez, George A. and Michael Stohl. "Liberalization and Redemocratization in Latin America: The Search for Models and Meanings," In Liberalization and Redemocratization in Latin America, eds. George A. Lopez and Michael Stohl, pages. New York: Greenwood Press, 1987. 
Lynch, Colum. "U.S.: Guatemala Army Must Fight Drug War." Miami Herald, 30 April 1990, in ISLA.

Malloy, James M. "The politics of Transition in Latin America," In Authoritarians and Democrats: Regime Transition in Latin America, eds. James $M$ Malloy and Mitchell A. Seligson, 235-258. Pittsburgh: University of Pittsburgh Press, 1987.

-..-. "Economic Crisis and Democratization: Latin America in the 1980s," In Latin American and Caribbean Contemporary Record vol. 8, eds. James M. Malloy and Eduardo Gamarra, PAGES???. New York: Homes and Meier, 1991.

Malloy, James M. and Eduardo A. Gamarra. Revolution and Reaction. New Brunswick: Transaction Books, 1988.

McCartney, Robert J. "Guatemala's New Ruler Moves Gingerly on Rights and Economy." Washington Post, 12 March 1986, in ISLA.

Mcclintock, John. "Colombians Turn to Guatemala for Cocaine Smuggling." Miami Herald, 23 November 1989, in ISLA.

Miller, Marjorie. "Families Call for Justice for Guatemala's Missing." Los Angeles Times, 21 January 1986, in ISLA.

Millett, Richard. "Guatemala: Progress and Paralysis." Current History (March 1985), 109-113.

"After the Elections." The New Republic

$(24$ February 1986): 18-20.

----.. "Guatemala," In Latin American and Caribbean Contemporary Record vol. 6, ed. Abraham F. Lowenthal, B299-B314. New York: Holmes and Meier, 1989.

"Limited Hopes and Fears in Guatemala."

Current History (March 1991): 125-128.

-.-.--. Phone interview by author, 16 March 1992.

Monje, Carlos. Lecture, Florida International University. Miami, FL, 2 February 1992.

Moreno, Dario. U.S. Policy in Central America: The Endless Debate. Miami: Florida International University Press, 1990 . 
-..-. Struggle for Peace in Central America. Gainsville: University of Florida Presses, forthcoming.

Nairn, Allan. "The Guatemala Connection." Progressive (May 1986): 20-22.

Nairn, Allan, and Jean-Marie Simon. "Bureaucracy of Death." The New Republic (30 June 1986): 13-17.

Nordlinger, Eric A. Soldiers in Politics. Englewood Cliffs, NY: Prentice Hall, 1977.

O'Donnell, Guillermo. "Introduction to the Latin American Cases," In Transitions from Authoritarian Rule: Latin America, eds. Guillermo O'Donnell, Philippe schmitter and Laurence Whitehead, 3-18. Baltimore: Johns Hopkins University Press, 1986.

o'Donnell, Guillermo and Philippe schmitter. Tentative Conclusions About Uncertain Democracies. Baltimore and London: Johns Hopkins University Press, 1986.

Painter, James. "Guatemala in Civilian Garb." Third World Quarterly 8 no. 3 (July 1986): 818-844.

--.---. Guatemala: False Hope, False Freedom. London: Catholic Institute for International Relations/Latin America Bureau, 1987.

Perera, Victor. "Chaos in the Scorched Earth." The Nation 28 January 1984): 92-95.

-----. "Uzi Diplomacy." Mother Jones (July 1985): $40-48$.

Pye, Lucien W. "Political Science and the crisis of Authoritarianism." American Political Science Review 84 no. 1 (March 1990): 3-18.

Rossiter, Caleb and Bonnie Tenneriello. "Can U.S. Military Aid Really Help a Civilian President?" Christian Science Monitor, 9 June 1988.

Rouquié, Alain. The Military and the state in Latin America. Berkeley: University of California Press, 1987. 
Rubenberg, Cheryl A. "The United states, Israel, and Guatemala: Interests and Conflicts," In Central America and the Middle East: The Internationalization of the Crisis, ed. Damian J. Fernandez, 94-121. Miami: Florida International University Press, 1990.

Sanford, Jonathan E. "Guatemala: U.S. Foreign Assistance Facts." Congressional Research Service, 11 June 1987.

Schirmer, Jennifer. "Waging War to Prevent War." The Nation (10 April 1989): 478-479.

Sereseres, Caesar D. "The Highlands War in Guatemala," In Lat in American Insurgencies, ed. Georges Fauriol, 98-130. Georgetown University center for strategic and International studies, 1985.

Sharckman, Howard. "The Vietnamization of Guatemala: U.S. Counterinsurgency Programs," In Guatemala, eds. Susanne Jonas and David Tobis, 193-203. Berkeley: North American Congress on Latin America, 1974.

SIPRI Yearbook 1991: World Armaments and Disarmament. New York: Oxford University Press, 1991.

Stepan, Alfred. Rethinking Military Politics: Brazil and the Southern Cone. Princeton: Princeton University Press, 1988 .

Torres-Rivas, Edelberto. Centroamérica: La Democracia Posible. Editorial Universitaria Centroamericana, 1987.

Repression and Resistance: The struggle for Democracy in Central America. Boulder: Westview Press, 1989 .

Trudeau, Robert. "The Guatemalan Election of 1985: Prospects for Democracy," In Elections and Democracy in Central America, eds. John A. Booth and Mitchell A. Seligson, 93125. Chapel Hill: University of North Carolina Press, 1989 .

-.--.. "Guatemala," In Latin American and Caribbean Contemporary Record vol. 8, eds. James M. Malloy and Eduardo Gamarra, B244-B256. New York: Holmes and Meier, 1991 . 
--.--. "Guatemala," to appear in Latin American and Caribbean Contemporary Record vol. 9, eds. James M. Malloy and Eduardo Gamarra. New York: Holmes and Meier, 1992.

United Nations. International Narcotics Control Board. Report of the International Narcotics Control Board for 1990. United Nations, 1990.

U.S. Congress. House. Committee on Foreign Affairs. Subcommittee on Western Hemisphere Affairs. United States Policy Toward Guatemala. Prepared statement of Caesar D. Sereseres. 98 th Cong., 1st sess., 1983. Committee print.

U.S. Congress. House. Committee on Foreign Affairs. U.S. Narcotics Control Programs overseas: A Continuing Assessment. 100th Cong., 1st sess., 1987. Committee Print.

U.S. Department of state. Country Reports on Human Rights Practices for 1990. Washington, D.C.: U.S. Government Printing office, 1991.

U.S. Department of state. Foreign Broadcast Information Service: Latin American Daily Report, 13 November 1984.

----. Foreign Broadcast Information Service: Latin America Daily Report, 5 August 1986.

-----. Foreign Broadcast Information Service: Latin America Daily Report, 8 August 1988.

Foreign Broadcast Information Service: Latin America Daily Report, 10 May 1989.

U.S. Government Accounting office. Military Sales: The Continuing Munition supply Relationship With Guatemala GAO/NSIAD-86-31, January 1986.

Wilkie, James W. and Enrique Ochoa, eds. Statistical Abstract of Latin America vol. 27. Los Angeles: UCLA Latin American Center Publications, University of California, 1989 .

Williams, Dan. "Guatemalan's 'Honeymoon' May Be Over." Los Angeles Times, 17 February 1987, in ISLA.

Woerner, Frederick D., retired U.S. General. Phone interview by author, 20 september 1991. 